\title{
THE UTILIZATION OF TRICARBOXYLIC ACID CYCLE INTERMEDIATES BY SALMONELLA TYPHIMURIUM
}

By

JANET A. ROWE

\begin{abstract}
A DISSERTATION PRESENTED TO THE GRADUATE COUNCIL OF THE UNIVERSITY OF FLORIDA

IN PARTIAL FULFILLMENT OF THE REQUIREMENTS FOR THE DEGRE OF DOCTOR OF PHILOSOPHY
\end{abstract}

UNIVERSITY OF FLORIDA

December, 1964 


\section{ACKNOWLEDGMENTS}

The author wishes to acknowledge the helpful guidance of Dr. Darrell B. Pratt and Dr. Mendel Herzberg during the course of these investigations. 
TABLE OF CONTENTS

Page

ACKNOWLEDGMENTS ...................... i i

LIST OF TABLES. ..................... . . v

LIST OF FIGURES ....................... vii

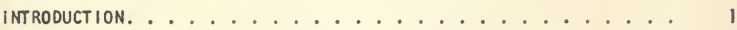

MATERIALS AND METHODS ...................... 8

Bacterial strains

Media

I nocula

Growth determinations

Gas chromatography

Thin film chromatography

Preparations of cell-free extracts

Enzyme assays.

Detection of radioactivity

EXPERIMENTAL RESULTS. ....................

1. Growth Studies

Survey of growth responses on solid media

Growth in liquid medla

Effect of growth medium of inoculum

Effect of size of inoculum

Effect of serial transfers in liquid medium

Growth pattern at high dilution

Effect of selection of colonies from solid media

The effect of intervening transfer of nonsuccinate

liquid medium on response to succinate

Growth yield constants

The effect of increasing concentrations of succinate

Effect of combinations of carbon sources

Effect of acetate in liquid culture

Response to addition of other compounds to liquid medium

Effect of addition of glutamate

Effect of addition of culture fluid from mutant 
TABLE OF CONTENTS (Continued)

Page

11. Respiration Studies

Respiration of whole cells on Krebs cycle compounds

Effect of added nitrogen source on respiration of succinate

Inhibitory effect of oxalacetate on succinic dehydrogenase Effect of starvation

Effect of cell concentration

Respiration of Krebs cycle compounds by cell-free extracts

111. Enzyme Studies

IV. Tracer Experiments

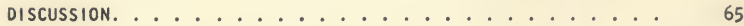

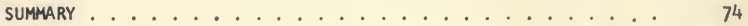

LIST OF REFERENCES. . . . . . . . . . . . . . . 76 


\section{LIST OF TABLES}

Table

Page

1 RESPONSE OF MUTANTS AND WILD TYPE TO VARIOUS

CARBON SOURCES AFTER 40 HOURS INCUBATION.

2 EFFECT OF INCREASING CONCENTRATIONS OF SUBSTRATES

ON RATE OF APPEARANCE OF GROWTH OF WILD STRAIN AND

MUTANT WITH VARIOUS CARBON SOURCES. . . . . . . . . .

3 THE EFFECT OF GROWTH MEDIUM OF INOCULUM ON RESPONSE

OF WILD STRAIN AND MUTANT TO SUCCINATE AS SOLE

CARBON SOURCE......................

4 THE EFFECT OF INOCULUM SIZE ON GROWTH OF THE WILD

STRAIN IN LIQUID MEDIUM WITH SUCCINATE AS SOLE

CARBON SOURCE....................

5 SIMPLIFIED FLUCTUATION TEST SHOWING THE EFFECT OF

SMALL INOCULA OF THE WILD TYPE ON ADAPTATION TO

SUCCINATE UTILIZATION

6 EFFECT OF A LARGE POPULATION OF SLOW-GROWING CELLS ON THE COLONY FORMING ABILITY OF A SMALL NUMBER OF

FAST -GROWI NG ORGANISMS.

7 EFFECT OF AN INTERVENING PERIOD OF GROWTH IN NONSUCCINATE LIQUID MEDIUM ON RATE OF GROWTH OF THE WILD STRAIN DURING SERIAL TRANSFER IN SUCCINATE MEDIUM.

8 EFFECT OF AN INTERVENING PERIOD OF GROWTH ON A NONSUCCINATE SOLIO MEDIUM ON THE RATE OF GROWTH OF THE WILD STRAIN DURING SERIAL TRANSFERS IN SUCCINATE MEDIUM. ...................

9 GROWTH YIELD CONSTANTS OF WILD STRAIN AND MUTANT GROWING ON A VARIETY OF SUBSTRATES...........

10 EFFECT OF INCREASING CONCENTRATIONS OF SUCCINATE ON THE RATE OF APPEARANCE OF GROWTH OF WILD STRAIN AND MUTANT....................

11 EFFECT OF INCREASING CONCENTRATIONS OF ACETATE ON GROWTH RATE OF THE WILD STRAIN WITH SUCCINATE AS PRINCIPLE CARBON SOURCE ............... 


\section{LIST OF TABLES (Continued)}

Table

Page

12 EFFECT OF ADDED KREBS CYCLE COMPOUNDS ON GROWTH OF WILD STRAIN WITH SUCCINATE AS

PRINCIPLE CARBON SOURCE ................

13 EFFECT OF ADDED GLUTAMATE ON GROWTH OF THE WILD STRAIN WITH SUCCINATE AS PRINCIPLE CARBON SOURCE ................ . . 40

14 OXIDATION OF KREBS CYCLE INTERMEDIATES BY MUTANT AND WILD STRAIN. . . . . . . . . . . . .

15 VARIATION AMONG DIFFERENT CELL MASSES IN RESPIRATORY ACTIVITY WITH SUCCINATE AS

SUBSTRATE ...................

16 SPECIFIC ENZYME ACTIVITY OF CELL EXTRACTS OF

WILD STRAIN AND MUTANT. . . . . . . . . . . . .

17 EFFECT OF ISOCITRITASE INDUCTION ON GROWTH OF THE MUTANT IN SUCCINATE MINIMAL BROTH . . . . . . . . UTILIZATION OF SUCCINATE BY INTACT CELLS. 


\section{LIST OF FIGURES}

Figure

Page

1 The effect of serial transfer of wild strain in succinate medium on its ability to grow rapidly with succinate as the sole carbon source.

Effect of added nitrogen source on the rate of oxidation of succinate and total oxygen uptake by mutant (. .) wild strain $(x--x)$.

3 The effect of oxalacetate on succinic dehydrogenase of cell extracts of wild strain $(x--x)$ and mutant (. .) as measured in the Warburg respi rometer with succinate as the substrate.

4 Effect of starvation on succinate oxidation by the wi ld strain, starved cells $(x--x)$ took up 6 ul of oxygen per hour per 0 . D. Unit, nonstarved (. .) took up 7.7 ul of oxygen per hour per 0 . D. Unit. .

5 Effect of decreasing cell density on rate of oxidation of succinate by the wild strain and mut ant.....................

0xygen uptake by cell extracts of wild strain $(x--x)$ and mutant (. .) with succinate as the substrate.

Oxygen uptake on $\mathrm{c}^{14}$ labeled succinate by whole cells of wild strain $(x--x)$ and mutant $(.$,$) .....$ 


\section{INTRODUCTION}

Thls dissertation describes the utilization by Salmonella typhimurium of succinate as sole carbon source. The initial observation indicated that two types of behavior could be observed in the different stralns, one was delayed utllization, that is, maximum growth not attalned until 60 to $80 \mathrm{hrs}$; the other was rapid utlllization, that is, maximum growth in 9 to $12 \mathrm{hrs}$. This phenomenon, not previously reported in the literature, was studied in an attempt to elucidate the mechanlsm accounting for the two types of behavior.

The experimental work was begun as a study of the characteristics of seven mutants produced by ultravlolet irradiation of the wild strain (Herzberg, 1962). These mutants were originally isolated, using the peniclllin technique of Davis (1948), on Davis -Mingloll medium. They were characterized by an inabillty to grow on this medium, which contained both glucose and citrate, unless it was supplemented with aspartate. That all of the mutants could utillze citrate as sole carbon source was obscured by the probable repression of citrate permease caused by the presence of glucose in the medium. When the mutants were tested in a number of other carbon sources It was found that they all grew readily with cltrate, but varied in their ability to utilize Krebs cycle four-carbon Intermediates. Thus the mutation produced by the irradiation represented a characteristic distinct from the abillty to grow on fourcarbon compounds. One mutant, designated $\times 39$, was selected for further study. This organism reached a maximum optical density within 
twenty-four hours when succinate was the sole carbon source; in contrast the wild strain required 60 to $80 \mathrm{hrs}$ to reach a similar density. The objective of this research was to determine the causes for this difference in time required to reach maximum growth.

Among the possible causes for this phenomenon the three considered most probable were (a) increased permeabillty of the mutant, which would permit it to concentrate, rapidly a large pool of internal succlnate, and thus to have utilizable substrate readily avaliable; (b) enhancement of the activity of Krebs cycle enzymes, which would allow a more rapid turnover rate so that more substrate could be metabolized in a given time; or (c) the release of internal catabolic inhibitors by the mutant so that succinate utilization could proceed freely. These, therefore, were the areas in which the investigation was centered.

of the above possibilities the increase in permeability was the easiest to test. Failure to account for variations in permeabllity has, In the past, led to erroneous conclusions concerning the function of the Krebs cycle in microorganisms. In their early Investigations Krebs and Johnson (1937) concluded that the cycle was absent in yeast and Escherichia coli because citrate was not oxidized at an appreciable rate by whole cells. Similarly, Karlsson and Barker (1948), using the technique of sequential induction, showed that cells of Azotobacter agilis, which were grown in acetate, were not able to oxidize a-ketogultarate, succinate, malate, or pyruvate, and they also concluded that the tricarboxylic acid cycle was not present in these organisms. Stone and Wilson (1952), using Azotobacter vinelandil, showed that nonproliferating cells required a period of time before they could oxidize succinate, 
fumarate, malate, or a-ketoglutarate, and that such cells failed to oxidize citrate. Cell extracts, however, were able to oxidize the substrates rapidly. Similar observations were made with other organisms: Campbell and Stokes (1951) had reported similar results in Pseudomonas aeruginosa which was grown on acetate. Lara and Stokes (1952) observed the oxidation of citrate by dried cells of Escherichia coll although the intact cells could not use 1t. Barrett et al. (1953) subsequently showed that a lag of seventy minutes occurred when Pseudomonal fiuorescens, grown in fumarate, was transferred to citrate. The cell extracts, however, did not show this lag. Ultraviolet Irradiation destroyed the ability of the cells to adapt to citrate. All of these observations are known, now, to be due to the necessity for induction of a permease, and this inductive capacity was destroyed by irradiation. The work of Saz and Krampitz (1955), using Micrococcus lysodeikticus, and of Ajl (1950) and Swim (1952) with Escherichia coli established that citrate could be readily oxidized by extracts of these organisms. Thus the failure to demonstrate citrate utilization by whole cells was due to the lack of substrate penetration, and not to the lack of the necessary oxidative enzymes.

Subsequent studies using radiolsotopes substantiated the presence of the Krebs cycle in these bacteria. Since these early studies the Krebs cycle has been demonstrated in Pseudomonas aeruginosa (Campbell) and Stokes, 1950), Aerobacter aerogenes (Gilvarg and Davis, 1956), Samonella typhosa and Salmonella paratyphi (Fukumi et al., 1953), Brucella abortus (Altenbern and Housewright, 1952), Mycobacterium tuberculosis (Goldman, 1956), Propionibacterium pentosaceum (Delwiche and 
Carson, 1953), and Rhodospirillum rubrum (Ei senberg, 1953). Presumably the cycle is present in all organisms which carry on an oxidative metabolism. Through it the cell derives the energy necessary to carry on cell functions, and the carbon skeletons for the formation of amino acids and other organic molecules. Thus the role played by the Krebs cycle is a central and most vital one in the over-all metabolism of the bacterial cell, and differences in enzyme activity might be expected to cause differences in the ability of a cell to grow with Krebs cycle intermediates as subst rates.

In 1957 Kornberg and Madsen demonstrated the presence of isocltritase and malate synthetase in extracts of pseudomonas grown on acetate as the sole carbon source, and proposed the glyoxylate cycle. This cycle serves to provide four-carbon compounds to the cell growing on two-carbon compounds by the condensation of glyoxylic acid and acetyl Coenzyme $A$ to form malate which is then oxidized through the usual Krebs cycle steps to isocitric acid. Isocitric acld is split by the action of I socitritase to glyoxylate and succinate which are recycled. In the organisms so far studied it has proved to be an inducible system. Reeves and AJI (1960), using E. colli, showed the presence of both isocitritase and malate synthetase in cultures grown on ribose or succinate, suggesting that induction is not limited to two-carbon units as was originally thought. The Krebs cycle and the glyoxylate cycle are closely interacting mechanisms, and so may be expected to exert a strong influence on one another.

While growth on the four-carbon Krebs cycle intermediates has not been previously established in Salmonella typhimurium. Englesberg 
(1961) did report that three mutants unable to grow on glucose could grow on the cltric acid cycle intermediates including the four-carbon acids. Further evidence of its abllity to ut llize citrate is its growth on Simmons cltrate agar which contains citrate as sole carbon source. Although the literature contains no reference to the study of the Krebs cycle in this organism, Kun and Abood (1949) demonstrated succinate oxi dizing activity in an endotoxin preparation from Salmonella aertrycke (typhimurium), and characterized the enzyme as succinic dehydrogenase. Further, most of the enzymes required for the operation of the Krebs cycle have been demonstrated in such closely related specles as $\underline{s}$.

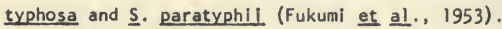

Another cause originally suggested for the slow growth of the wild strain on succinate medium was the action of internal inhibitors. Efficient metabolism of the cell requires a strict regulation of reaction systems. Because of its essential role in over-all metabolism of the cell this regulation is especially important in the case of the Krebs cycle. One means of controiling the cycle is by the action of inhibitors formed catabolically. While there is iittle information available concerning such an effect on the other steps of the Krebs cycle, the IIterature does contain many examples relating to succinic dehydrogenase. As far back as 1937 Das, using enzyme preparations from mamalian tissue, showed that succinic dehydrogenase could be Inhibited by the product of a reaction several steps removed from it, oxalacetate. This effect was studied more extensively by Pardee and Potter (1948). They observed that addition of oxalacetate to rat liver mitochondrla which were respirlng succinate caused a transitory inhibition. Subsequent experiments using 
succinlc dehydrogenase showed that the effect was due to a competitive Inhibition, oxalacetate having an affinity for the enzyme whlch was one thousand times greater than that of the substrate. A similar inhibitory effect of oxalacetate was reported by Stone and Wilson in 1952 when they showed that cell extracts prepared from azotobacter could oxidlze cltrate, a-ketoglutarate, fumarate, and malate rapidly, but succinate oxidation was much slower. They further demonstrated that the initial rapid rate of oxygen uptake on the other four acids fell to the level of succinate oxidation after ten to twenty minutes. Upon analysls of the reaction mixtures they were able to demonstrate a fourfold greater accumulation of oxalacetate with succlnate as the substrate than in the controls. An inhibition of succinate respiration in rat liver mitochondria by added glyoxylate has also been reported (Ruffo, Adinolfi, Budillon and Capobianco, 1962), but no such effect has been observed in bacterial syst ems.

The literature reviewed has provided a precedent for the three explanations for the slow growth of the wild strain with succinate whlch were suggested earlier. With these in mind the problem was approached through a series of growth studies, which demonstrated the stimulatory effect of glutamate and acetate on growth of the wild strain with succinate.

Examinat lon of the comparative respiratory activities did not demonstrate any large differences between the organisms, nor did a survey of Krebs cycle and related enzymes, with the exception of Isocltratase. From respiratory data it was concluded that permeability differences were not a major factor in the problem. The second hypothesls, 
that Krebs cycle enzyme activity was enhanced in the mutant, was also not supported by experimental evidence. The results of the growth studles suggested that, of the possibilities mentioned in the beginning, internal regulation was the most IIkely. In view of the many reported cases of succinic dehydrogenase inhibition by oxalacetate it seemed posslble that some similar effect was occurring in these organisms. However, the experiments using radiol sotopes falled to show any accumulation of oxalacetate or other Krebs cycle Intermediates. The rapld oxidation of succinate by resting cells confirmed this result. The conclusion on the basis of the evidence obtained, was that the failure of the wild strain to grow with succinate as the sole carbon source was not directly associated with the tricarboxylic acid cycle. The phenomenon may be due to a regulatory process presently unknown, or to a fallure of one of the associated reactions leading to amino acid formation. 
MATERIALS AND METHODS

Bacterial strains. The strain of Salmonella typhymurium used was a virulent one, designated strain 7, obtained from the Florida State Bureau of Laboratories, Jacksonville, Florida, and described by Herzberg (1962). Stock cultures were maintained on trypticase soy agar slants at room temperature, and transferred at approximately monthly intervals. Occasionally these cultures acquired the ability to grow rapidly with succinate. Slowly growing cells were reisolated using a peniclilin technique modified from that of Davis (1949). Cells grown on giucoseaspartate medium were I noculated into succinate broth and incubated for four hours. At the end of this period 200 units per mi of penicillin were added and the culture was incubated for an additional eighteen hours. A loopful of this culture was then streaked on trypticase soy agar plates. Those colonles appearing on trypticase soy agar whlch failed to grow within 24 hrs when tested on succinate agar were subcultured and kept as stocks.

The organism, designated $\times 39$, was one of a group of seven mutants produced by ultraviolet irradiation of strain 7, and isoiated by the penicillin technique of Davis (1948). Ali of these mutants showed a requirement for high concentrations of aspartate when growing on a glucose minimal medium (Herzberg, 1962). The optimal concentration was 250 ug per ml (normal range for an amino acid is 10 to 50 ug [Lamanna and Mallette, 19531).

Media. The basal mineral salts medium used in this study was composed of $\mathrm{K}_{2} \mathrm{HPO}_{4}, 3.5 \mathrm{~g} ; \mathrm{KH}_{2} \mathrm{PO}_{4}, 1.5 \mathrm{~g} ;\left(\mathrm{NH}_{4}\right)_{2} \mathrm{SO}_{4}, 2.6 \mathrm{~g}$; distilled 
water, I liter. Substrates were made up as 2 per cent solutions in water and added to give a finai concentration of $2 \mathrm{mg}$ per $\mathrm{mi}$ unless otherwise stated. Fumarate, malate, and aspartate were made up as 2 per cent solutions of the free acids, and neutralized by the addition of $\mathrm{NaOH}$. Succinate, acetate, and citrate were made up as 2 per cent solutions of the sodium saits. The basai medium, at pH 6.8, was sterilized in the autoclave at $121 \mathrm{C}$ and 15 lbs pressure for fifteen minutes. One $\mathrm{ml}$ of a sterile solution of trace minerals was added aseptically after sterillzation. This solution was composed of $\mathrm{MgSO}_{4} \cdot 7 \mathrm{H}_{2} \mathrm{O}, 10 \mathrm{~g}$; $\mathrm{MnSO}_{4} \cdot 7 \mathrm{H}_{2} \mathrm{O}, \mathrm{I} \mathrm{g}$; $\mathrm{FeSO}_{4} \cdot 7 \mathrm{H}_{2} \mathrm{O}, 0.1 \mathrm{~g}$; concentrated $\mathrm{HCl}, 3 \mathrm{ml}$; distilled water to $100 \mathrm{ml}$. For solid media a highly purified agar (Ionagar No. 2, distributed by Consolidated Laboratories, Inc., Chicago Helghts, 111 inois) wes added to give a final concentration of 0.85 per cent. Aspartate was added to give a final concentration of 0.02 per cent, and glucose to a final concentration of 0.2 per cent when preparing glucose-aspartate mineral medium. Trypticase Soy Agar (Baltimore Blological Laboratories) was prepared according to standard di rections.

Inocula. Unless otherwise stated, the cells for all inocula were grown overnight in glucose-aspartate medium on a rotary shaker at $37 \mathrm{C}$, and harvested by centrifugation. They were washed three times by centrifugation and resuspension in distilled water, and finally resuspended in distilled water. This suspension was used immediately as a source of inoculum. Density was estimated in the spectronic "20" spectrophotometer at $425 \mathrm{mu}$.

Growth determinations. Twenty milliliters of the appropriate medium was put into $250 \mathrm{ml}$ flasks bearing a side arm for the estimation 
of turbidity. They were inoculated to a final concentration of $10^{6}$ cells per $\mathrm{ml}$ and incubated on a rotary shaker at $37 \mathrm{C}$. Growth was estimated by the increase in turbidity at $425 \mathrm{mu}$ in the Spectronic "20" spectrophotometer (Bausch and Lomb 0ptical Company, Rochester, New York).

Respi rometer experiments. Oxygen uptake was measured according to the method described by Umbreit, Burris, and Stauffer (1964), using the Warburg respirometer. The cells for respiration experiments were grown ten hours in glucose-aspartate mineral medium, and harvested by centrifugation. They were washed three times and resuspended in dis tilled water to an optical density of about 60 . This was determined by diluting the suspension $1 / 100$, and measuring spectrophotometrically. One $\mathrm{ml}$ of the suspension was added to the main compartment of a Warburg vessel containing 300 umoles of phosphate buffer, $\mathrm{pH} 6.8$, and water to a final volume of $3 \mathrm{ml}$, with air as the gas phase. Carbon dioxide was absorbed in $0.2 \mathrm{ml}$ of 20 per cent $\mathrm{KOH}$ contained in the center well. A fifteenminute period was allowed for temperature equilibration, followed by a second fifteen-minute period during which endogenous respiration was measured at five-minute intervals. Unless otherwise stated all reactions were started by tipping in substrate from the side arm.

Gas chromatography. Gas chromatography was used to detect acetic acid. The acid was separated on a polyethyleneglycol monosterate column at a temperature of $79 \mathrm{C}$ with nitrogen as the gas phase, and utilizing a Loenco Hydrogen Flame Detector (Lee Engineering Company, Pasadena, Callfornia). The method is sensitive to 0.1 umole per $\mathrm{ml}$ of acetic acid. Thin film chromatography. This method was used for the Identification of organic and amino acids. The film material, Silica Gel $G$ and 
MN-Cellulose powder 300 (average particle size, $10 \mathrm{u}$ ), was obtained from the Brinkmann Instrument Company, Great Neck, New York. Slurries were prepared and applied to glass plates as di rected (Brinkmann Manual, 1963).

The a-keto acids, as the 2,4 dinitrophenylhydrazone derivatives, were applied in 20 ul volumes to Silica Gei G plates and developed two hours in a solvent system consisting of toluene, acetic acid, water $(4: 3: i, v / v)$. After drying the plates the yellow spots could be identified by their Rf values wi thout further treatment (Bush and Hockaday, 1963).

The 2,4 dinitrophenylhydrazones were prepared according to the method of Grundig (1961). A trichloroacetic acid extract of the broken cells was added to an equal volume of a 0.1 per cent solution of 2,4 dinitrophenylhydrazone in $2 \mathrm{~N} \mathrm{HCl}$. The reaction was allowed to proceed for forty-five minutes at room temperature. The 2,4 dinitrophenylhydrazones were extracted from the aqueous solution with ethylacetate. The solvent was evaporated under a stream of air, and the residue dissolved in 95 per cent ethanol. This solution was used for chromatography. Fatty acids were applied to cellulose films and developed two hours in a solvent system consisting of water-saturated butanol and formic acid $(95: 5, v / v)$. The plates were dried to remove the volatile formic acid and the spots located with the aid of a spray consisting of 0.3 per cent brom cresol green in 80 per cent methanol to which eight drops per $100 \mathrm{mi}$ of 30 per cent $\mathrm{NaOH}$ had been added. Fatty acids appeared as yellow spots on a blue background (Lederer and Lederer, 1953). 
Amino acids were applied to Sillica Gel G plates and developed two hours in a solvent system consisting of isopropanol, acetic acld, water $(3: 1: 1, v / v)$. Spots were located by spraying the plate with 0.1 per cent ninhydrin in butanol. The plate was heated about ten minutes at $110 \mathrm{C}$. Amino acids appeared as purple or rose colored spots on a white background.

Preparations of cell-free extracts. Cells were grown overnight in giucose-aspartate mineral medium, washed three times with $0.3 M$ phosphate buffer, pH 6.8, and resuspended in buffer. The cells were disrupted in the Hughes Press (Hughes, 1951) or when more suitable, in the French Pressure Cell (Milner, Lawrence, and French, 1950). The resulting extract was centrifuged at $27,000 \times \mathrm{g}$ for 30 minutes to remove debris and unbroken cells, and the clear supernatant fluid was used as a source of enzyme without further purification. Enzyme preparations not used immediately were stored frozen at $-20 \mathrm{C}$. Protein determinations of these preparations were done according to the method of Lowry (195i).

Enzyme asșays. Succinic dehydrogenase was measured according to the method of Burnath and Singer (1962). The reactlon was carrled out in a Warburg flask contalning 150 umoles phosphate buffer, $\mathrm{pH} 7.6 ; 0.5$ $\mathrm{ml}$ crude enzyme; distilled water to a final volume of $3 \mathrm{ml}$ in the main compartment. The side arm contained 1.5 umoles sodium succinate; 0.17 umoles phenazine methosulfate; 0.3 umoles $\mathrm{KCN}$. The center well contained $0.2 \mathrm{mi}$ of a 20 per cent $\mathrm{KOH}$ solution to absorb $\mathrm{CO}_{2}$. Oxygen uptake was measured against a blank lacking substrate. 
Fumarase was assayed according to the method of Racker (1950). The following reagents were measured into a sillca cuvette: 150 umoles of phosphate buffer, $\mathrm{pH} 7.4 ; 150$ umoles of malate recrystallized from butanol; $0.01 \mathrm{ml}$ crude enzyme; distilled water to give a final volume of $3 \mathrm{ml}$. The reaction was followed in a Spectronic " 505 " recording spectrophotometer (Bausch and Lomb Optical Company, Rochester, New York) at 300 mu against a blank lacking substrate.

Triphosphopyrridinenucleotide-malate dehydrogenase was measured according to the method of Ochoa, Mehler, and Kornberg (1948), except that trihydroxymethylaminomethane (Tris) buffer was substituted for glycylglycine buffer. The reaction tube contained 50 umoles of Tris buffer, $\mathrm{pH} 7.4 ; 1.0$ umole of $\mathrm{MgCl}_{2} ; 1.0 \mathrm{mg}$ trlphosphopyrridinenucleotide; 100 umoles of potassium malate; $0.05 \mathrm{ml}$ of crude enzyme; distilled water to a total volume of $3 \mathrm{ml}$. The increase in optical density was measured in a Spectronic "505" recording spectrophotometer at 340 mu against a blank lacking substrate.

Glutamic dehydrogenase was assayed according to the procedure of 01 son and Anfinsen (1955). The following reagents were measured into a $3 \mathrm{ml}$ silica cuvette: $0.05 \mathrm{mg}$ triphosphopyrridinenucleotide; 270 umoles phosphate buffer, pH 7.5; 66 umoles sodium glutamate; $0.02 \mathrm{ml}$ crude enzyme; distilled water to a final volume of $3 \mathrm{ml}$. The increase in optical density at 340 mu was estimated in the spectronic " 505 " recording spectrophotometer against a blank lacking substrate.

0xalacetic decarboxylase was assayed according to the method of Burton and Krebs (1955). The reaction was carried out in a Warburg flask containing 330 umoles acetate buffer, $\mathrm{pH} 5.4 ; 30$ umoles $\mathrm{MnSO}_{4} ; 1 \mathrm{ml}$ crude 
enzyme; distilled water to give a final volume of $3 \mathrm{ml}$. The side arm contained 30 umoles of oxalacetic acid, $\mathrm{pH} 5.4$. The evolution of $\mathrm{CO}_{2}$ was measured two and five minutes after tipping; the volume of gas evolved during this threeminute interval was a measure of enzyme activity. The two control flasks were one lacking enzyme, the other lacking substrate. I socitritase was assayed according to the method of Reeves and Ajl (1960). The 3-ml reaction mixture contained 200 umoles phosphate buffer, $\mathrm{pH} 7.0 ; 15$ umoles $\mathrm{MgSO}_{4} ; 10$ umoles phenylhydrazine hydrochlorlde; 0.26 umoles cysteine hydrochloride; $0.1 \mathrm{ml}$ crude enzyme. The reaction was initiated by the addition of 10 umoles of $1-i$ socitrate. The increase in absorption at 324 mu was followed in the Spectronic "505" recording spectrophotometer using a blank lacking substrate.

Aspartase was assayed according to the method of Williams and Mclntyre (1955). A tube containing 30 umoles phosphate buffer, pH 6.8; 20 umoles aspartate; $0.3 \mathrm{ml}$ crude enzyme in a total volume of $1 \mathrm{ml}$, was incubated in a $37 \mathrm{C}$ water bath for twenty minutes. One-tenth volume of 25 per cent TCA was added and the precipitated protein removed by centrifugation. The ammonium ion in the supernatant fluid was determined (Williams and Mclntyre, 1955).

Detection of radioactivity. Radioactivity in cell extracts and $\mathrm{CO}_{2}$ was detected with the aid of a Packard tricarb liquid scintillation spect rometer (Packard Instrument Company, LaGrange, IIIinois). 


\section{EXPERIMENTAL RESULTS}

The experimental results have been divided into four general categories. The section on growth studies describes the variations in growth patterns between the wild strain and the mutant under a variety of conditions, and possible Interpretations of the observations. The second section is devoted to studies concerning the comparative oxidative capaclties of the two strains, while the third section presents the results of a survey of the enzymatlc constitution of the two strains. The fourth section comprises a radiolsotope experiment designed to demonstrate a block in the Krebs cycle of the wild strain if one existed.

\section{i. Growth Studies}

Survey of growth responses on solld medla. The inltial experiment was a survey of the ability of the mutants requiring aspartic acid to grow with various Krebs cycle components as carbon sources. This survey was conducted both with and without glucose as an additional carbon source. One loopful of a dilute cell suspension was streaked on agar plates contalning the various carbon sources: growth was assessed as confluent or isolated colonies on the:agar surface. The results (Table I) showed that all mutants grew readily with citrate in the absence, but not in the presence, of glucose. The mutants were grouped into three classes on the basis of their growth pattern on the other carbon sources. Those which grew on succinate, fumarate, citrate, and malate in the absence of glucose, and on succinate with glucose were classed as Type I. included 


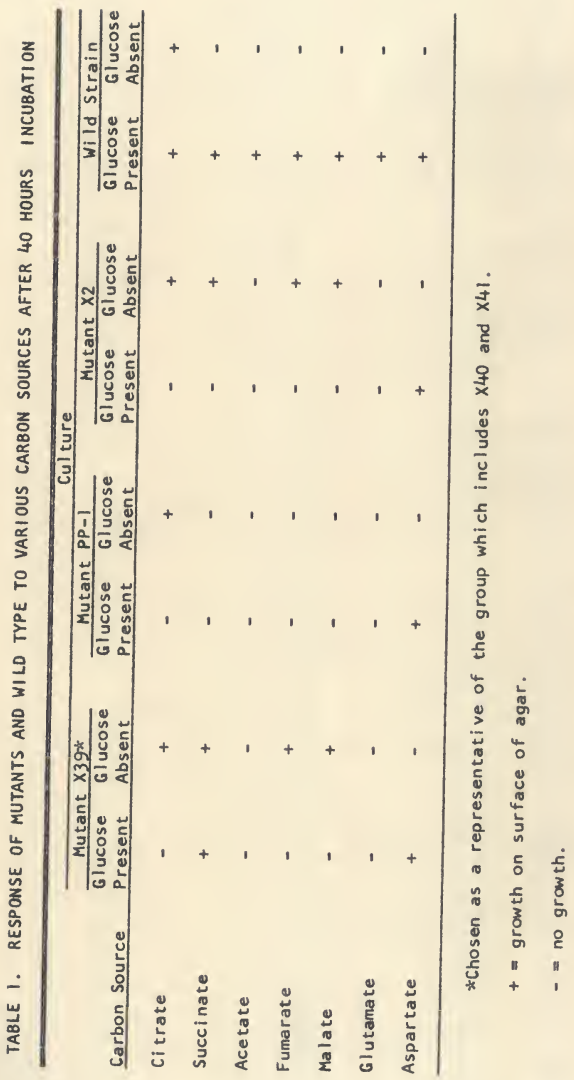


in this group were $X 39, X 40$, and $X 41$. PP -1 , which grew only on citrate in the absence of glucose, was Type $1 \mathrm{i}$. In this respect it was similar to the wild type. However, the wild straln was not impaired in its growth on glucose, and thus, grew on ali plates which contained this substrate. Type III was mutant $X 2$ which grew on malate, fumarate, and succinate in the absence of glucose, but not in its presence. None of the organisms tested could grow on aspartate or glutamate alone; this has been shown in other organisms to be due to impermeability of the cells to these substrates (Umbarger, 1961). The data in Table 1 show also that growth of all of the mutants on citrate was Inhibited in the presence of glucose. Gilvarg and Davis (1955) have shown in Aerobacter aerogenes that this effect is caused by the repression by glucose of a permease specific for citrate. in addition one mutant, $X 2$, also showed a repression by glucose when growing on succlnate; this suggested that glucose prevented the induction of a succinate permease in this organlsm. This led to the speculation that the inabllity of the wild strain to grow readily on succlnate might, simllarly, be due to the necesslty for induction of a permease, which would be constitutive in the mutants of Type $i$. The difference between the wild strain and the mutants of Type $i$ in their abillty to grow with succinate as the sole carbon source provided the subject for the remainder of this Investigation. To simplify the technical work one mutant, X39, was chosen for further study since it grew well in the glucose-aspartate medium.

Growth in Liquid media. The growth response pattern which was seen on the plates was confi rmed in liquid medla (Table 2). Starting with an inocuium of $10^{6}$ cells, maximum turbidity of the wild strain was 
TABLE 2. EFFECT OF INCREASING CONCENTRATIONS OF SUBSTRATES ON RATE OF APPEARANCE OF GROWTH OF WILD STRAIN AND MUTANT WITH VARIOUS CARBON SOURCES

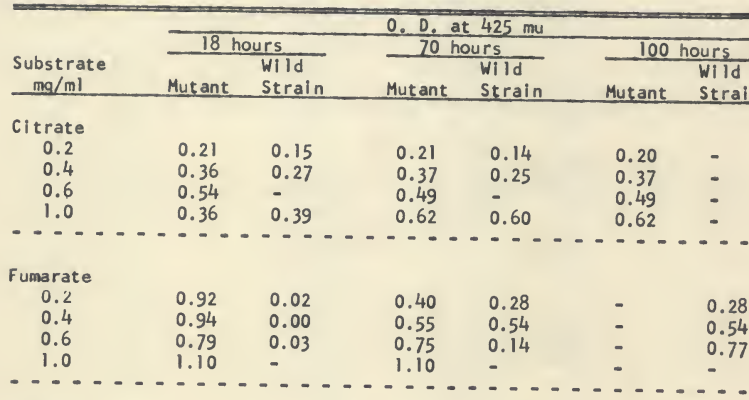

Malate
0.2
0.4
0.15
0.02
0.31
0.02
0.41
0.01
0.56
0.02
0.25
0.45
0.60
0.15
1.0
0.77
0.30
0.48
0.65

Succinate
0.2
0.4
0.15
0.00
- $\quad 0.00$
0.00
0.00
0.00
$-\quad 0.00$
$-\quad 0.01$
$\begin{array}{ll}- & 0.13 \\ - & 0.04 \\ - & 0.48 \\ - & 0.66\end{array}$
0.6
1.0
0.44
0.00
$0.65 \quad 0.01$
$\therefore$

Acetate
0.4
0.8
0.00
0.02
0.00
0.02
1.2
0.00
2.0
0.00
0.00
0.00
$\begin{array}{ll}- & 0.01 \\ - & 0.02 \\ - & 0.01 \\ - & 0.05\end{array}$
0.00
0.00
0.00
0.00
0.00
0.00
0.06
$0.23 *$

*0. D. was 0.65 at 103 hours.

- = no measurement taken. 
reached earliest in the citrate medium at about twenty-one hours incubation. Growth in malate was complete at about forty-six hours incubation. The cells inoculated into fumarate required seventy to eighty hours incubation to reach full growth, but growth in succinate was not completed unt il well after eighty hours incubation. The mutant, however, showed a more rapid growth rate on all substrates. Substantial growth on succinate, malate, fumarate, and cltrate was apparent within fourteen hours, and all cultures had reached maximum turbidity by elghteen hours. The final optical densities of the mutant and the wild strain growing on any one substrate did not differ to any appreciable degree, suggesting that both were eventually able to utilize the substrates (see Table 2).

Effect of growth medium of inoculum. The failure of the wild type to grow readily with succinate as the sole carbon source might have been due to the lack of an essential precursor or to the accumulation of an internal inhibitor during growth of the inoculum in glucose-aspartate minimal broth. A different growth medium might promote the formation of such a precursor or prevent the accumulation of an inhibitor. Three different media were tried to determine whether any effect could be detected. Since glucose repression had been observed in an earlier experiment, the possibility that deletion of thls substrate might perhaps prevent the formation of a repressor was explored. Therefore, a complex medium with and without the addition of glucose, and a synthetic medlum containing citrate as the carbon source were used. The synthetic glucose-aspartate medium was also included as a control.

Cells which had been grown on citrate did appear to respond to succinate at a rate slightly faster than that of the glucose-aspartate 
grown cells (Table 3 ). The rate of growth, however, was still far below that of the mutant. The other growth media did not appear to effect the growth rate on succinate. Since the effect was not striking it was concluded that the inoculum growth medium did not contribute significantly to the formation of internal cofactors or inhibltors.

Effect of size of Inoculum. it had been observed in the wild strain that Inocula of the order of $10^{8}$ to $5 \times 10^{8}$ organisms per milliliter resulted in a very much shortened lag on succinate. This phenomenon suggested that (1) critical levels of some essential growth factor were being inoculated together with the cells or (2) mutation to succinate utilization was occurring, and mutants were present in the large inocula. This experiment was designed to provide evidence for or against the first hypothesis. The growth flasks were inoculated so that they initially contained $10^{6}, 10^{7}, 10^{8}$, and $5 \times 10^{8}$ cells per $\mathrm{ml}$ of succinate minimal medium. The results (Table 4) showed that the length of the lag period was dependent upon the size of the inoculum. If this phenomenon were due to the addition of some essential growth factor it should have been depleted after several division cycles. Therefore, the cells from the $5 \times 10^{8}$ inoculum were harvested, resuspended in saline and reinoculated Into succinate medium at two levels of concentration, 106 and about $5 \times 10^{8}$ cells per $\mathrm{ml}$. These cells presumably having depleted the possible growth factor accumulated during growth on glucose should display the prolonged lag. The results showed a shortened lag in both cases (Table 4), and serial transfers reduced it to the same level as the succinate posltive mutant. 
TABLE 3. THE EFFECT OF GROWTH MEDIUM OF INOCULUM ON RESPONSE OF WILD STRAIN AND MUTANT TO SUCCINATE AS SOLE CARBON SOURCE

\begin{tabular}{|c|c|c|c|c|c|c|}
\hline \multirow{2}{*}{$\begin{array}{l}\text { Growth } \\
\text { Medlum } \\
\text { pf Inoculum }\end{array}$} & \multirow[b]{2}{*}{ Strain } & \multicolumn{5}{|c|}{ 0. D. at $425 \mathrm{mu}$ in $0.05 \%$ succinate } \\
\hline & & 0 Hrs & $13 \mathrm{Hrs}$ & 24 Hrs & 48 Hrs & $72 \mathrm{HrS}$ \\
\hline \multirow{2}{*}{$0.2 \%$ trypticase } & Mut ant & 0.05 & 0.19 & 0.34 & 0.34 & 0.34 \\
\hline & Wild strain & 0.03 & 0.04 & 0.04 & 0.18 & 0.24 \\
\hline $\begin{array}{l}0.2 \% \text { t rypticase } \\
+0.2 \% \text { glucose }\end{array}$ & $\begin{array}{l}\text { Mutant } \\
\text { Wild strain }\end{array}$ & $\begin{array}{l}0.03 \\
0.04\end{array}$ & $\begin{array}{l}0.37 \\
0.05\end{array}$ & $\begin{array}{l}0.35 \\
0.05\end{array}$ & $\begin{array}{l}0.34 \\
0.06\end{array}$ & $\begin{array}{l}0.34 \\
0.32\end{array}$ \\
\hline $\begin{array}{l}0.2 \% \text { glucose } t \\
0.2 \% \text { aspartate }\end{array}$ & $\begin{array}{l}\text { Mutant } \\
\text { Wild strain }\end{array}$ & $\begin{array}{l}0.03 \\
0.03\end{array}$ & $\begin{array}{l}0.31 \\
0.05\end{array}$ & $\begin{array}{l}0.32 \\
0.05\end{array}$ & $\begin{array}{l}0.30 \\
0.05\end{array}$ & $\begin{array}{l}0.30 \\
0.35\end{array}$ \\
\hline \multirow[t]{2}{*}{$-\cdots-\cdots$} & $\ldots .$. & 0 & at 425 & mu in 0. & $\%$ succin & - - \\
\hline & & 0 Hrs & 2 Hrs & $24 \mathrm{Hrs}$ & $48 \mathrm{Hrs}$ & $84 \mathrm{Hrs}$ \\
\hline \multirow{2}{*}{$0.2 \%$ cltrate } & Mut ant & 0.115 & 0.81 & 0.81 & - & 0.75 \\
\hline & Wild strain & 0.19 & 0.30 & 0.45 & 0.50 & 0.85 \\
\hline $\begin{array}{l}0.2 \% \text { glucose } t \\
0.02 \% \text { aspartate }\end{array}$ & $\begin{array}{l}\text { Mutant } \\
\text { Wild strain }\end{array}$ & $\begin{array}{l}0.125 \\
0.20\end{array}$ & $\begin{array}{l}0.64 \\
0.18\end{array}$ & $\begin{array}{l}0.85 \\
0.25\end{array}$ & $\overline{0.29}$ & 0.85 \\
\hline
\end{tabular}

- no measurement made. 
TABLE 4. THE EFFECT OF INOCULUM SIZE ON GROWTH OF THE WILD STRAIN IN LIQUID MEDIUM WITH SUCCINATE AS SOLE CARBON SOURCE

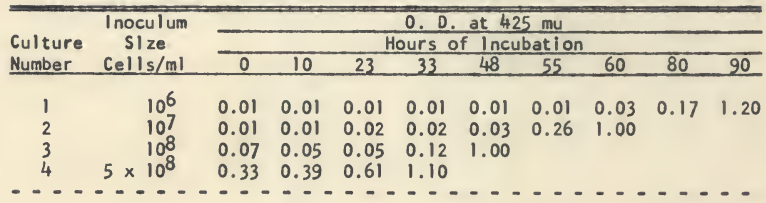

Subcultured from Culture Number 4 Above

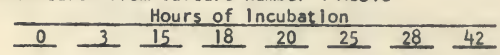

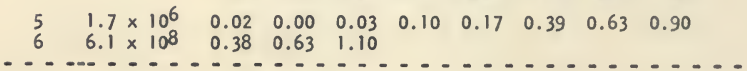

Subcultured from Culture Number 6 Above Hours of Incubation

Hours of Incubation
$0 \quad 2 \quad 5 \quad 8 \quad 2.5 \quad 11 \quad 22$

$\begin{array}{lllllllll}7 & 4.7 \times 10^{6} & 0.01 & 0.01 & 0.03 & 0.10 & 0.23 & 0.43 & 0.95 \\ 8 & 4.7 \times 10^{8} & 0.31 & 0.44 & 1.10 & & & & \end{array}$

Subcultured from Culture Number 7 Above*

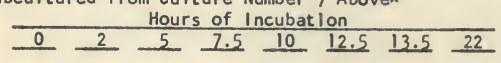

$\begin{array}{rlllllllll}9 & 10^{6} & 0.00 & 0.00 & 0.00 & 0.01 & 0.04 & 0.15 & 0.23 & 0.91 \\ 10 & 10^{8} & 0.12 & 0.10 & 0.31 & 0.82 & 1.00 & & & \end{array}$

*Cells were first washed and incubated in glucose-aspartate mineral medium for 10 hours. They were then washed and inoculated into succinate broth. 
The more rapld growth of large Inocula might have been due to the presence of a critical level of some precursor. If that were the case the larger inocula should have grown to a glven turbldity much more rapIdly than the smaller. Each tenfold dilution of the Inoculum represents about three generatlons; therefore, the tlme required to reach a given turbidity should be increased by three generation tlmes for each dllutlon, assuming nothing is added with the Inoculum. The generation time on succlnate calcuiated from the logarlthmic part of the growth curves of Table 2 is 2.75 hrs. Therefore, it should take the $10^{6}$ inoculum 8.25 hrs longer than the $10^{7}$ inoculum to reach an 0 . D. of about 0.17 . As calculated from the table the time required was actually about twenty hours. Simllarly the 107 inoculum required about twenty-seven hours longer than the $10^{8}$ inoculum to reach a slmilar density. This is equal to about 7.3 generations In the flrst case and to about 9.5 in the second. This experiment, therefore, did not rule out the theory that an essential metabolite was belng Inocuiated with the celis, but it provlded no evidence that such a pool could be exhausted.

Effect of serial transfers in llquld medium. Several experlments were done in an effort to determine the nature of the eventual adaptation of the wlld strain to succinate utillzatlon. Two possibilities were considered: the cells whlch grew out on succinate represented either a mutation to the ablitity to utilize succlnate rapldly or a physiologlcal adaptation resulting from formation of an Induclble enzyme or critlcal levels of an essentlal precursor.

The experlments to test the hypothes ls were deslgned on the premise that if growth represented a mutation the large Inocula would 
probably contain a mutant while the probabillty of including a mutant in a very small inoculum would be low. Serial transfers of the wild strain were made in succinate broth or high and low inoculum levels. Rapid growth should occur in flasks with large inocula, but no growth should appear In those with small inocula. As a control these same inocula were also plated on succinate agar and on trypticase soy agar, and the plates observed for colony formation.

The cells which were inoculated at high levels grew considerably faster than those with small inocula (Figure I). Subsequent transfers from flasks containing the large I nocula did not substantially alter the growth time in liquid, but a difference was noted on solid media. Growth on plates, after the second transfer, was visible in only twenty-four hours. A second transfer from flasks with small Inocula did show a substantial reduction in time required to reach visible turbidity. The posslbility of a physiological adaptation was not ruled out by this experiment. Serial transfers on the same medium would tend to reinforce such an adaptation.

Growth pattern at high dilution. If adaptation of the wild strain to succinate utillzation were the result of mutation then extensive dilution should reduce the probability of a mutant being present in a small sample. In this experiment a series of 76 tubes were inoculated with about $10^{3}$ cells each, contained in five $\mathrm{ml}$. Presumably none of these tubes would contain a mutant. If, however, any did they would be expected to become turbid while the rest would remain clear. The tubes were incubated in stationary racks at $37 \mathrm{C}$ which resulted in less oxygen being available than in shaken cultures. All of the tubes eventually 


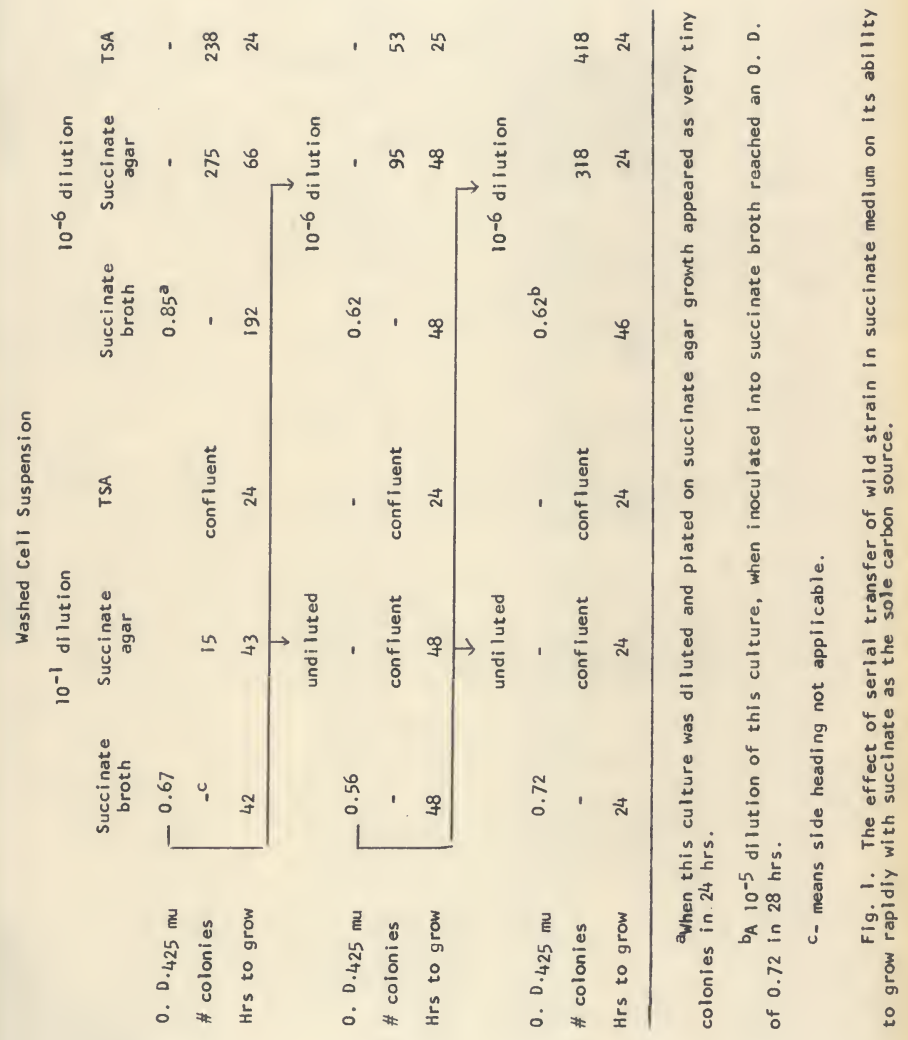


became turbid (Table 5). This seemed at first to indicate that not a mutation, but a physiological adaptation had occurred. However, as was shown prevlously by Engelsberg and Stanier (1.949) in pseudomonas, it was also possible that sufficient background growth had occurred on impurities in the medium to permit a mutation to occur, and that this mutant was responsible for the observed growth. The possibility of an extremely high mutation rate, of the order of one in $10^{3} \mathrm{cell} / \mathrm{s}$, was not ruled out.

Effect of selection of colonies from solld media. An experiment in which colonies were cultivated on solld medium was designed to give more definitive evidence for or against a mutation of the wild strain to succinate utilization. In this experiment a washed cell suspension was plated at high dilution on succlnate agar. When colonies appeared ten were picked and transferred to trypticase soy agar plates. A second passage on trypticase soy agar was made and then one colony from each plate was picked and transferred to succinate agar. On these plates isolated colonies appeared after 72 hrs. Several of these were again picked and streaked on trypticase soy agar plates. When growth appeared another transfer to succinate was made, and isolated colonies again failed to appear before 72 hrs. This experiment showed that no fastgrowing colony appeared on succinate agar, and the results suggest that adaptation to succinate utilization is, at ieast for the colonles selected, a physiological adaptation which can be lost when the cells are transferred to a medium which does not contain succinate as a carbon source.

To determine whether a small number of rapidly growing organisms could be detected in a large population of slow-growing cells a mixture 
TABLE 5. SIMPLIFIED FLUCTUATION TEST SHOWING THE EFFECT OF SMALL INOCULA\# OF THE WILD TYPE ON ADAPTATION TO SUCCINATE UTILIZATION

\begin{tabular}{ccc}
\hline Days Incubation & $\begin{array}{c}\text { Number of Tubes } \\
\text { Becoming Turbid }\end{array}$ & $\begin{array}{c}\text { Cumulative Total to } \\
\text { Turbid Tubes }\end{array}$ \\
\hline 4 & 6 & 6 \\
6 & 15 & 21 \\
7 & 14 & 35 \\
8 & 20 & 55 \\
11 & 21 & 76 \\
\hline
\end{tabular}

*I noculum slze was $10^{3}$ organisms per tube.

Note: A total of 76 tubes were inoculated; each containing $5 \mathrm{ml}$ of succinate medium. 
of large numbers of the slow and small numbers of the fast strains was plated on succinate agar. Several ratios were plated to see if the presence of a sufficient number of fast-growing cells could stimulate the growth of the slow strain. Small numbers of fast-growing cells were readily detected in a large population of slow-growing organisms, and, in the mixtures used, they do not influence the rate of growth of the slow strain (Table 6). After sixty-six hours many small colonies of the slowgrowing strain did appear on the plates. The experiment also showed that there were no, or very few, fast-growing cells in a population as large as $10^{6}$ slow-growing organisms.

The effect of intervening transfer of nonsuccinate liquid medi um on response to succinate. The previous experiments seemed to provide equivocal results: the selection of colonies from solld media suggested that only a physiological adaptation, which was lost during cultivation on a medium lacking succinate, had occurred while the modified fluctuation test suggested a mutation, but did not rule out a physlological adaptation. Another experiment was designed to determine which of these interpretations was correct. The inoculum was grown in glucose-aspartate minimal broth and distributed in 10 flasks containing $20 \mathrm{ml}$ of succinate minimal medium, at a concentration of $10^{3}$ cells per flask. These were permitted to grow to maximal optical density, which was limited by the concentration of succinate. They were then harvested, washed once, diluted to $10^{3}$ cells per $\mathrm{ml}$, and one $\mathrm{ml}$ inoculated Into glucose-aspartate minimal broth. The cells were harvested after about $36 \mathrm{hrs}$, washed once, and diluted to $10^{3}$ cells per $\mathrm{ml}$. One $\mathrm{ml}$ of this suspension was inoculated into succi nate minimal broth and the time required to reach maximal turbidity 
TABLE 6. EFFECT OF A LARGE POPULATION OF SLOW-GROWING CELLS ON THE COLONY FORMING ABILITY OF A SMALL NUMBER OF

FAST -GROWING ORGANISMS

\begin{tabular}{|c|c|c|}
\hline $\begin{array}{l}\text { Ratlo of number of } \\
\text { fast-growing cells } \\
\text { to slow-growing } \\
\text { cells } \times 100 \\
\end{array}$ & $\begin{array}{c}\text { Number of fast- } \\
\text { growing cells: } \\
\begin{array}{c}\text { slow-growing } \\
\text { cells }\end{array}\end{array}$ & $\begin{array}{l}\text { Number of colonles } \\
\text { formed in } 42 \text { hours }\end{array}$ \\
\hline $1 / 170$ & $140 / 2.4 \times 10^{6}$ & 168 \\
\hline $1 / 17$ & $140 / 2.4 \times 10^{5}$ & 138 \\
\hline $1 / 1.7$ & $140 / 2.4 \times 10^{4}$ & 142 \\
\hline $1 / 0.17$ & $140 / 2.4 \times 10^{3}$ & 155 \\
\hline $1 / 0$ & $140 / 0$ & 140 \\
\hline $0 / 2400$ & $0 / 2.4 \times 10^{3}$ & None \\
\hline
\end{tabular}


recorded. As shown in Table 7 all of the cultures had completed growth in 24 to 36 hrs. Growth was again limited by succinate concentration. A mutant control reached maximum optical density in 33 hrs, while an unadapted wild strain control required a minimum of $120 \mathrm{hrs}$. Thus it appeared that growth on succinate was a mutation which was not lost even when the cells were transferred to a medium lacking succinate.

To insure that the population growing in the glucose-aspartate medium was actually composed of mutants, the cells from the succinate were harvested, washed once, diluted and plated on succinate and on glucose-aspartate agar plates. One colony from each of triplicate glucose-aspartate plates was picked, suspended in water, and diluted to $10^{3}$ cells per $\mathrm{ml}$. One $\mathrm{ml}$ of this suspension was transferred to succinate minimal broth as before. In this case also, cultures reached maximum turbidity in 24 to $36 \mathrm{hrs}$ (Table 8 ). It was, therefore, concluded that the cells finally growing in succinate minimal broth were actually mutants which had acquired the ability to ut llize succinate rapidiy.

Growth yield constants. In a mineral broth the total yield of bacterla per unit of substrate tends to be constant for a given species (Novick, 1953). The size of this total yield will be a measure of the efficiency of the cell on a given carbon source. This, in turn, should give an indication of the metabolic pathway in the cell, since it is un likely that two different pathways will operate with the same efficiency to give the same total yield. This aspect was examined in the hope that it would provide a clue to the fallure of the wild type to grow on succlnate. Growth yield constants, expressed as optical density units per mg of substrate, were determined on succinate, fumarate, malate, and citrate 
TABLE 7. EFFECT OF AN INTERVENING PERIOD OF GROWTH IN NONSUCCINATE LIQUID MEDIUM ON RATE OF GROWTH OF THE WILD STRAIN DURING SERIAL TRANSFER IN SUCCINATE MEDIUM

\begin{tabular}{|c|c|c|c|c|}
\hline \multirow[b]{2}{*}{ Flask number } & \multicolumn{4}{|c|}{ Hours to reach maximum turbidity } \\
\hline & $\begin{array}{c}\text { Ist } \\
\text { transfer }\end{array}$ & $\begin{array}{c}\text { 2nd } \\
\text { transfer }\end{array}$ & $\begin{array}{c}\text { Wild } \\
\text { strain }\end{array}$ & Mutant \\
\hline 1 & 150 & 30 & 120 & 33 \\
\hline 2 & 190 & 30 & 126 & 33 \\
\hline 3 & 80 & 36 & & 33 \\
\hline 4 & 175 & 36 & & \\
\hline 5 & 120 & 36 & & \\
\hline 6 & 102 & 24 & & \\
\hline 7 & 150 & 30 & & \\
\hline 8 & 152 & 30 & & \\
\hline 9 & 167 & 24 & & \\
\hline 10 & 106 & 28 & & \\
\hline
\end{tabular}

*Inoculum size was 1000 cells per flask. 
TABLE 8. EFFECT OF AN INTERVENING PERIOD OF GROWTH ON A NONSUCCINATE SOLID MEDIUM ON THE RATE OF GROWTH OF THE WILD STRAIN

DURING SERIAL TRANSFERS IN SUCCINATE MEDIUM

\begin{tabular}{|c|c|c|c|c|}
\hline \multirow[b]{2}{*}{ Flask number } & \multirow{2}{*}{$\begin{array}{c}\text { Ist } \\
\text { transfer }\end{array}$} & \multirow{2}{*}{$\begin{array}{c}\text { 2nd } \\
\text { transfer }\end{array}$} & \multicolumn{2}{|c|}{ Number of colonies ${ }^{b}$} \\
\hline & & & Glu-aspa & Succinate \\
\hline 1 & 120 & 36 & 96 & 94 \\
\hline 2 & 126 & 36 & 240 & 231 \\
\hline
\end{tabular}

Glu-asp = Glucose-aspartate agar.

${ }^{a} A$ total of five colonies picked from glucose-aspartate plates and inoculated into succinate minimal broth.

bo prepare plates the cells were harvested from the Ist succlnate transfer and diluted to a concentration of about $103 \mathrm{cell} / \mathrm{s} / \mathrm{ml}$. One-tenth $\mathrm{ml}$ of the dilution was then spread on the surface of the agar plates. 
basal media. Flasks were inoculated with $4 \times 10^{7}$ cells and incubated until no further change in optical denslty could be detected.

The organisms showed no differences in total yields with any of the Krebs cycle intermediates, but the time required to attain these yields varied considerably (Table 9). This result suggested that there was no radical difference in the pathways for the utllization of these substrates. The difference was in rate only, and this may represent the time required for enzyme induction, or for the accumulation of some essential intermediate in the wild type which can be made at a rapid rate by the mutant. This implies a rate-limiting reaction step.

The effect of increasing concentrations of succinate. As suggested earlier the slow growth of the wild type in the succinate medium could be a result of a deficiency in a permease. Entry of the substrate would then depend solely upon diffusion. Therefore, if a high concentration of succlnate were used the rate of penetration by diffuslon should be increased, the increase being dependent upon concentration. If no internal metabollc block were involved growth should proceed more rapidly, and a concentration level should be obtained which would permit a growth rate comparable to that of the mutant. When levels greater than 5 per cent succinate were used almost complete inhibltion of growth occurred In the mutant, and even at 5 per cent a strong inhibitory effect was noted $(T$ able 10$)$. At 3 per cent and 4 per cent succinate a slight stimulation of growth of the wild strain did occur, but in no case did the rate of appearance of the wild strain reach a level equal to that of the mutant. The wild straln was not totally lmpermeable, but may have been only slowly permeable. One ought to see, in thls case, if 
TABLE 9. GROWTH YIELD CONSTANTS* OF WILD STRAIN AND MUTANT GROWING ON A VARIETY OF SUBSTRATES

\begin{tabular}{lcc} 
& \multicolumn{2}{c}{$0.0 .425 \mathrm{mu} / \mathrm{mg}$ of substrate } \\
\cline { 2 - 3 } Substrate & Mutant & Wild strain \\
\hline Succlnate & 1.50 & 1.50 \\
Citrate & 1.30 & 1.20 \\
Malate & 1.10 & 0.80 \\
Fumarate & 0.90 & 1.20 \\
\hline
\end{tabular}

*Growth yield constant is defined as the increase in optical density of the culture at $425 \mathrm{mu}$ with each increase in mg of substrate. 
TABLE 10. EFFECT OF INCREASING CONCENTRATIONS OF SUCCINATE ON THE RATE OF APPEARANCE OF GROWTH OF WILD STRAIN AND MUTANT

\begin{tabular}{cccccc}
\hline $\begin{array}{c}\text { Succinate } \\
(w / v)\end{array}$ & $\begin{array}{c}\text { Maximum } \\
0.0 .\end{array}$ & $\begin{array}{c}\text { Hours to reach } \\
\text { maximum } 0.0 .\end{array}$ & $\begin{array}{c}\text { Maximum } \\
0.0 .\end{array}$ & $\begin{array}{c}\text { Hours to reach } \\
\text { maximum } 0 . \quad 0 .\end{array}$ \\
\hline 0.2 & 0.55 & 24 & 0.52 & 72 \\
1.0 & 1.5 & 24 & 1.52 & 72 \\
2.0 & 2.0 & 24 & 1.90 & 72 \\
3.0 & 2.0 & 36 & 2.0 & 60 \\
4.0 & 1.9 & 36 & 1.5 & 48 \\
5.0 & 0.68 & 60 & 2.00 & 72 \\
6.0 & 0.20 & 72 & 0.05 & 72 \\
10.0 & 0.04 & 72 & 0.07 & 72 \\
\hline
\end{tabular}

Optical density measured at $425 \mathrm{mu}$. 
there were no other complicating factors, a slower but detectable rate of appearance of growth before eight hours when high concentrations of succinate were used. Thls did not occur; as is seen from Table 10 there is a long lag followed by rapid growth. On the basis of these results permeability was considered not to be the only factor in the failure of the wild strain to grow rapidly on succinate, although it may be a contributing cause.

Effect of comblnations of carbon sources. This serles of experiments was designed to determine whether it was posslble to enhance growth of the wild strain by the addition of a secondary carbon source. It was hoped that some compound might be found whlch would act as a growth stlmulant, perhaps by supplylng some necessary metabolite which the cell was unable to syntheslze or could syntheslze only slowly. Thus, it would provide an Indication of the nature of the metabolic block. Amino acids were chosen simpiy to determine if any effect could be observed. Wild strain cells were streaked on plates containing two milllgrams of the test substances per $\mathrm{ml}$ of basal medium plus $2 \mathrm{mg}$ of succinate per $\mathrm{ml}$. Plates were Incubated at $37 \mathrm{C}$. Growth of the wild strain appeared in $24 \mathrm{hrs}$ on plates supplemented with acetate or alanine, and traces of growth appeared on those contalning cystelne, lysine, or hyst ldlne. No other compound promoted growth, and no growth appeared on the succinate control piates until after $60 \mathrm{hrs}$ incubation. Because of its widespread role in metabolism and its prominent enhancement of growth in thls experiment, it seemed reasonable to suppose that the active compound was acetate, and that alanlne was in reality supplyit it through a 
transamination and decarboxylation. Therefore, a more definltive experiment was designed to test the effect of acetate in liquid medium. Effect of acetate in liquid culture. A series of flasks containing increasing concentrations of acetate in combination with 0.2 per cent succinate was prepared. If acetate were actually required for growth, rather than acting as a sparker or cofactor, then growth should show a concentration dependence.

A definite correlation of increase in optical density with increase in concentration of acetate was observed (Table 11 ). At the lower levels the culture required longer to reach maxlmum turbidity, but in every case the combination of acetate plus succinate gave a higher total yield than either substrate alone. This result suggested that a suboptimal internal concentration of acetate $\mathrm{mlght}$ be the growth-limiting factor when succinate was the sole carbon source.

Response to addition of other compounds to llayid medium. if fai iure to grow rapidly on succinate was due to a block in the Krebs cycle or ancillary reactions it might be possible to stimulate growth by supplying the product of the blocked enzyme if it is permeable. Therefore, the effect of adding Krebs cycle intermedlates or related compounds was investigated. Cells for the inoculum were harvested and washed as described in Materials and Methods. They were resuspended in a small volume of distilled water and $0.05 \mathrm{ml}$ used to inoculate the growth flasks giving an initial concentration of about $5 \times 10^{6}$ to $1.2 \times$ 107 cells per $\mathrm{ml}$.

of the compounds tried only glycine and pyruvate igave any appreciable stimulation, although a slight effect was noted with cltrate and 
TABLE 11. EFFECT OF INCREASING CONCENTRATIONS OF ACETATE ON GROWTH RATE OF THE WILD STRAIN WITH SUCCINATE AS PRINCIPLE CARBON SOURCE

\begin{tabular}{|c|c|c|c|c|c|}
\hline $\begin{array}{l}\text { Acetate } \\
\mathrm{mg} / \mathrm{ml}\end{array}$ & $\begin{array}{c}\text { Succi nate } \\
\mathrm{mg} / \mathrm{ml}\end{array}$ & $0.0_{\frac{1}{9} \text { at } 425}$ & $\frac{\mathrm{mu} \mathrm{0.0.} \text { at }}{19 \mathrm{hrs}}$ & it $\frac{425 \mathrm{mu}}{29 \mathrm{hrs}}$ & 46 hrs \\
\hline - & 2.0 & 0.03 & 0.04 & 0.10 & 0.20 \\
\hline 2.0 & - & 0.06 & 0.14 & 0.23 & 0.29 \\
\hline 0.1 & 2.0 & 0.01 & 0.04 & 0.21 & 0.74 \\
\hline 0.2 & 2.0 & 0.09 & 0.63 & 0.77 & - \\
\hline 0.0 .6 & 2.0 & 0.47 & 0.83 & 0.90 & - \\
\hline 0.8 & 2.0 & 0.80 & 0.93 & 0.95 & - \\
\hline 1.1 .0 & 2.0 & 0.80 & 0.90 & 1.00 & - \\
\hline
\end{tabular}

- z no measurement taken. 
glyoxylate (Table 12). The cultures growing in pyruvate alone became turbid after twenty-four hours, but those cultures growing in the succinate-pyruvate mixture reached a greater optical density indicating that both substrates were utilized. These results supported the sugges tion that the active compound was acetate arising from glycine by deanimation and from pyruvate by decarboxylation.

Effect of addition of glutamate. The stimulatory effect of acetate or acetate precursors suggested another explanation in addition to, or assoclated with, the depleted acetate pools. Failure to grow on succinate might also be due to accumulation of some internal inhibitor which was removed or blocked by acetate. The most obvious posslbility was oxalacetic acid, which has been reported to competively inhibit succinic dehydrogenase in mitochondria (Pardee and Potter, 1948). If oxalacetate were accumulating, glutamate would also be expected to remove it by a transamination giving rise to aspartate from oxalacetate and to a-ketoglutarate from glutamate.

Growth in the succinate-glutamate combination did show a dependence on concentration of glutamate (Table 13). The optical density increase, however, was delayed due, presumably, to the slow permeation of glutamate. Cultures incubated in the succinate-glutamate mixture showed a final total yield which far exceeded that of either substrate alone. When the cell-free culture fluid was chromatographed on thin film no glutamate spot could be detected.indicating that it had been utilized by the cells. Addition of oxalacetate to the basal medium containing glutamate or acetate in addition to succinate did not produce the expected inhibltion of growth, but rather a stimulation. Thls effect was 
TABLE 12. EFFECT OF ADDED KREBS CYCLE COMPOUNDS ON GROWTH OF WILD STRAIN WITH SUCCINATE AS PRINCIPLE CARBON SOURCE*

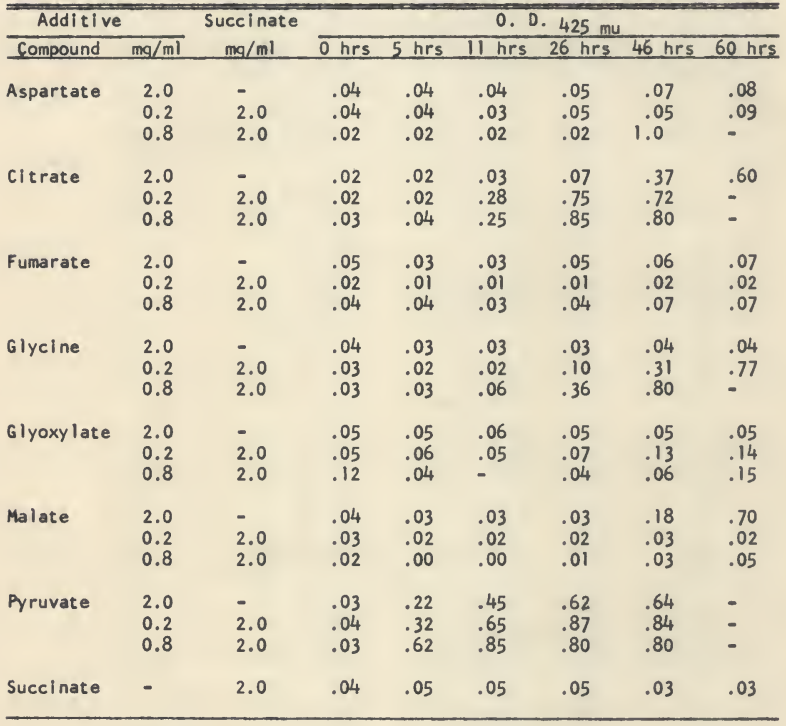

- no data. medi um.

*Succinate and additives were added to the mineral salts basal 
TABLE 13. EFFECT OF ADDED GLUTAMATE ON GROWTH OF THE WILD STRAIN WITH SUCCINATE AS PRINCIPLE CARBON SOURCE

\begin{tabular}{ccccc}
\hline $\begin{array}{c}\text { Glutamat e* } \\
\mathrm{mg} / \mathrm{ml}\end{array}$ & $\begin{array}{c}\text { Succinate* } \\
\mathrm{mg} / \mathrm{ml}\end{array}$ & \multicolumn{3}{c}{$0.0 .425 \mathrm{mu}$} \\
\cline { 3 - 5 } & 2.0 & .07 & $4 \mathrm{hrs}$ & $24 \mathrm{hrs}$ \\
0.1 & 2.0 & .03 & .025 & .05 \\
0.3 & 2.0 & .05 & .03 & .075 \\
0.5 & 2.0 & .09 & .03 & .08 \\
1.0 & 2.0 & .11 & .06 & .49 \\
2.0 & 2.0 & .07 & .04 & 1.4 \\
2.0 & - & .03 & .01 & .07 \\
\hline
\end{tabular}

*Carbon sources were added to minimal salts basal medium. 
possibly due to the formation of pyruvate from the spontaneous decarboxylation of oxalacetate; this compound is extremely unstable at room temperature in neutral pH (Merck Index); the stimulatory effect of pyruvate on growth has al ready been shown.

Effect of addition of culture fluid from mutant. The possibillty that the mutant might produce a cofactor which was required by the wild type was investigated. It seemed reasonable that if growth of the wild type was prevented by lack of an end product of a blocked reaction, the mutant by virtue of its rapid growth and metabolism $\mathrm{might}$ produce a substantial quantity of such an end product, and that it $\mathrm{mlght}$ accumulate in the medium. This culture fluid would, then, upon addition of more succinate, support the growth of the wild type. This idea was tested in the following experiment.

An inoculum of the mutant, which had been grown in glucoseaspartate minimal broth, was added to $20 \mathrm{ml}$ of succinate basal medlum to glve a final concentration of $2 \times 10^{6} \mathrm{cells}$ per $\mathrm{ml}$. This culture was incubated on a shaker in a $37 \mathrm{C}$ water bath. When optical density at 425 mu reached 0.75 , cells were removed by filtration through a millipore filter. Forty $\mathrm{mg}$ of succinate were added to about $20 \mathrm{ml}$ of the filtrate to give a concentration of 0.2 per cent. Trace minerals were also added, and the filtrate was inoculated with the wild strain to a concentration of $2 \times 10^{6}$ cells per $\mathrm{ml}$. A control was also inoculated into fresh succinate broth at the same denslty. Both cultures were Incubated in a water bath shaker at $37 \mathrm{C}$, and growth was followed by increase in optical density at $425 \mathrm{mu}$. A mutant control was also included. 
The growth of the wild strain on succinate was markedly stimulated by the mutant culture fluid, but it still exhibited a lag which was longer than that of the mutant. A lag of more than 23 hrs occurred before growth of the wild strain gave visible turbidity whereas the mutant exhibited a lag of less than $10 \mathrm{hrs}$. The control wild type whlch was inoculated into fresh succinate medium did not show any increase in optical density after sixty hours.

The culture fluid from the mutant control was recovered when the culture reached an optical density of about 0.70 , and chromatographed in an attempt to identify the active component. A $2 \mathrm{ml}$ sample was acidifled with 10 per cent $\mathrm{H}_{3} \mathrm{PO}_{4}$ and passed through the gas chromatographic column to detect acetate. No peak was registered in the acetate area, although an acetate control gave a very strong peak. The method is sensitive to 0.5 umoles per $\mathrm{ml}$ so it must be concluded that less than this amount was present in the culture fluid; therefore, the stimulatory compound was not acetate. Thin film chromatography showed that less than 4 umoles per $\mathrm{ml}$ of the four-carbon Krebs cycle acids were present, since this amount is the limit of the sensitivity of the method. When a chromatograph was prepared to show amino acids a single pale spot of about the same mobility as alanine was observed. The presence of alanine in the culture fluid would account for stimulation of growth since it was shown previously that it was effective in promoting growth. It must be pointed out that alanine and glutamate run very close together in the solvent system used, and the unknown spot was somewhat diffuse. Glutamate cannot, therefore, be excluded as the stimulatory substance. 


\section{Respiration Studies}

Respiration of whole cells on Krebs cycle compounds. Growth experiments designed to test the permeabillty of the cell to succinate have shown that increasing concentrations of substrate do not markedly stimulate the growth of the wild type. There appeared from the results of that experiment to be some slight difference in permeability, but not sufficient to explain the great dlfference in growth rate. Further the stimulatory effects of acetate or glutamate seemed to indicate that failure to permeate, alone, could not explain slow growth of the wild type with succinate. An experlment was undertaken to test the abllity of whole cell suspensions to oxidize succinate and other Krebs cycle compounds. If failure to grow were due solely to lack of succinate permeation this should be detectable in the Warburg respirometer. The cell which is not permeable to the substrate wlll not concentrate succinate internally at the same rate as one which is permeable; consequently a reduced rate of oxygen uptake should be observed.

The cell suspension used in this experiment was prepared as described in the materials and methods section. One $\mathrm{ml}$ of a suspension made up to a known optical density was used. The substrates were added In $0.2 \mathrm{ml}$ quantities from 0.2 per cent stock solutions. The results showed that cltrate was not oxidized measurably by either straln. This substrate has been shown to be impermeable to many cells until the induction of a permease occurs (GIlvarg and Davis, 1955). Of five trials the rate of oxygen uptake with succinate as the substrate was higher in the wild strain in two and in the mutant in three. The results (Table 14) in all cases, however, did show a substantlal degree of resplration 
TABLE 14. OXIDATION OF KREBS CYCLE INTERMEDIATES BY MUTANT AND WILD STRAIN*

\begin{tabular}{|c|c|c|c|c|}
\hline Substrate & Trial No. & \multicolumn{2}{|c|}{ ul $\mathrm{O}_{2}$ / hour/ $0.0^{\prime} 425 \mathrm{mu}$ Unit } & $\begin{array}{l}\text { Ratio of } \\
\text { mutant } \\
\text { wild type }\end{array}$ \\
\hline \multirow[t]{5}{*}{ Succinate } & 1 & 1.95 & 6.60 & 0.30 \\
\hline & 2 & 4.66 & 2.78 & 1.68 \\
\hline & 3 & 2.00 & 6.00 & 0.32 \\
\hline & 4 & 2.14 & 1.43 & 1.49 \\
\hline & 5 & 6.94 & 3.72 & 1.86 \\
\hline Fumarate & 1 & 4.45 & 2.85 & 1.56 \\
\hline Malate & 1 & 3.11 & 1.78 & 1.74 \\
\hline Citrate & 1 & 0.00 & 0.00 & 0.00 \\
\hline
\end{tabular}

*Figures represent ul $\mathrm{O}_{2}$ taken up after subtraction of endogenous respiration. 
on succinate in both strains, so that lack of permeation cannot be the major explanation for the very delayed growth of the wild type on this substrate. Further, as al ready pointed out permeabllity differences cannot explain the effect of acetate and glutamate. It must be concluded, therefore, that failure of succinate to permeate the wild type cell is, at most, only a contributing factor in the delayed growth phenomenon. The mutant showed a more rapld oxidation rate when fumarate or malate was the substrate. This result may be due to greater permeability of the mutant to these substrates, since the succinate was oxidized almost to completion in most cases by both stralns, and this would require that the steps through malate and fumarate be functlonal.

\section{Effect of added nitrogen source on respiration of succinate.}

The previous experiment showed no pronounced reduction in oxidation rate of whole cells on succinate, nor a delay in the initiation of oxidation. Since, therefore, failure of the wild strain to grow readlly on succinate could not be due to lack of permeation, it was proposed that the block might be an inhibition of one of the assimilatory pathways. To test thls idea 150 micromoles of ammonium sulfate were included in the main compartment of the Warburg vessel. Other conditions were the same as in the preceding experiment. If a block in assimi lation was occurring in the wild type the addition of a nitrogen source should have no effect. If this was not the case then ammonium sulfate should have provided growth promoting conditions resulting in a lower total oxidation since some of the carbon would be diverted into assimi latory pathways. The results (Figure 2) of two tests showed that an average reduction of oxygen uptake of about 50 per cent did occur in the case of 


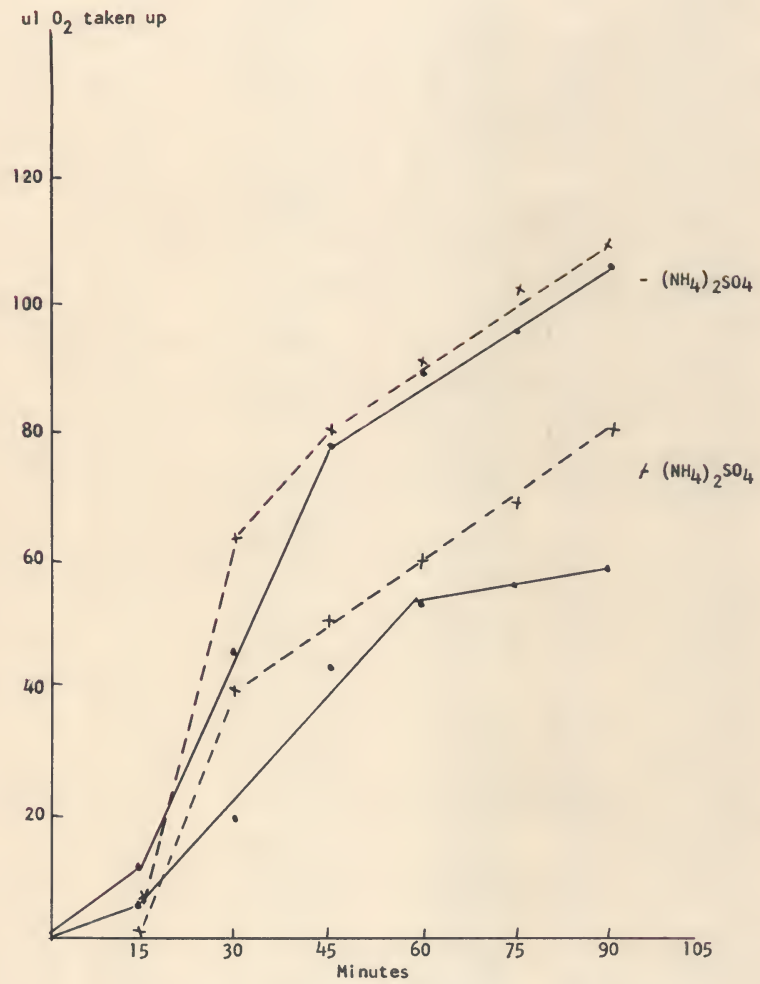

Fig. 2. Effect of added nitrogen source on the rate of oxidation of succinate and total oxygen uptake by mutant (. - .) wild strain $(x--x)$. Endogenous has been subtracted. 
the mutant, and of about 30 per cent in the case of the wild strain. This difference, al though not large, was considered significant. In a second trial the reduction in oxygen uptake by the wild type in the presence of ammonium sulfate was only about 11 per cent. It appeared, therefore, than an inhibition of assimilation was occurring, but this apparently was not a complete block. Further, the results of this experiment did not localize the block. The conditions of this experiment were very close to the conditions for growth, except for the lack of trace minerals in the respiratory experiment, and thus it was not unexpected that this result should be obtained.

Inhibitory effect of oxalacetate on succinic dehydrogenase. The results of the growth experiments suggested that an inhibitor might be accumulating within the cell which could be overcome by the addition of acetate or glutamate; this compound might possibly be oxalacetate. Oxalacetate is known to be a potent inhibitor of succinic dehydrogenase, and has been shown to cause a reduction of oxygen uptake by mitochondria respiring succinate (Pardee and Potter, 1948). The experiment described in this section was designed to determine the susceptibility of the enzymes in extracts of these organisms to such an inhibition.

A definite reduction in the rate of oxygen uptake by the cell extracts in the presence of oxalacetate was observed (Figure 3). This depression was especially pronounced in the extract of the wild strain during the first fifteen minutes of respiration. During this time only 14 ul of oxygen were consumed in the flask containing oxalacetate as compared to 88 ul by the control. After this time there seemed to be a slight release of the inhibition. During the next fifteen-minute period 


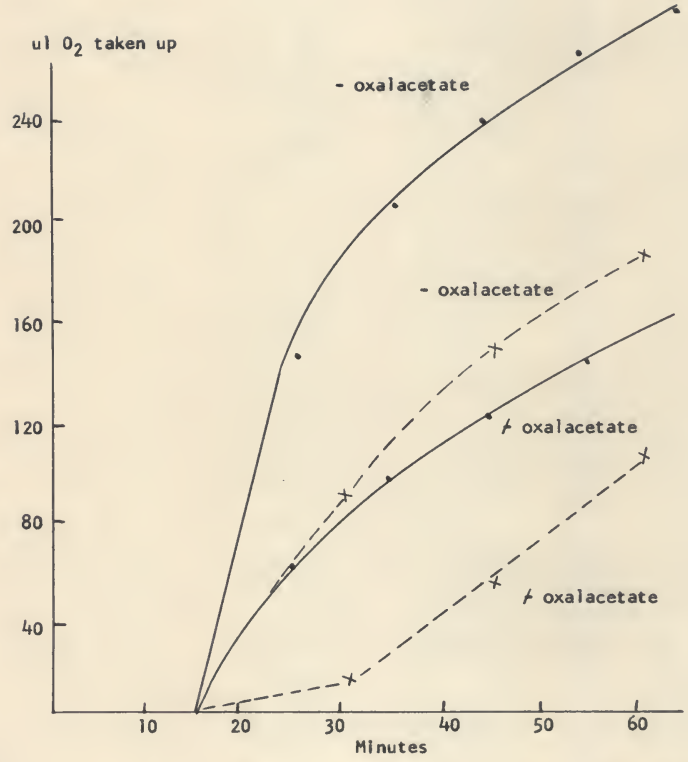

Fig. 3. The effect of oxalacetate on succinic dehydrogenase of cell extracts of wild strain $(x--x)$ and mutant $(.$.$) as measured$ in the Warburg respirometer with succinate as the substrate. 
37 ul of oxygen were taken up in the flask containlng inhibltor while the control consumed 57 ul of oxygen. Pardee and Potter (1948) reported that oxalacetate was gradually decarboxylated spontaneously to pyruvate, resulting in a gradual release of inhibition. This may account for the Increasing rate of oxygen uptake seen in the inhibited mixtures in this experiment. The succinic dehydrogenase activity of the extract prepared from mutant cells was also inhibited by oxalacetate, but the early stages of the inhibltion were far less pronounced than those of the wild strain. In another experiment oxalacetate was added to whole cell suspensions of the wild strain which were resplring succinate, and no inhlbition was noted.

Effect of starvation. Starvation of the wild strain cells might promote the depletion of internal pools of metabolites. If such pools are present the cell has these metabolites readily avallable and the rate of succinate oxidation should be steady from the start. Starved cells should show a rapid initial rate of oxidation until the pools are replenished. Thus a difference in the initial rates of oxidation between starved and nonstarved cells should be seen. Failure of the starved cells to oxidize succinate could also be due to exhaustion of an essential cofactor.

A suspension of washed cells, 0 . 0 . of 0.60 , was shaken eight hours in phosphate buffer. The cells were then harvested as usual, and oxygen uptake with succinate as the substrate was measured in the Warburg respirometer. Freshly harvested, nonstarved cells were also tested as a control. The results (Figure 4) showed that the rate of oxygen uptake by nonstarved cells was 22.1 per cent higher than that of the starved 


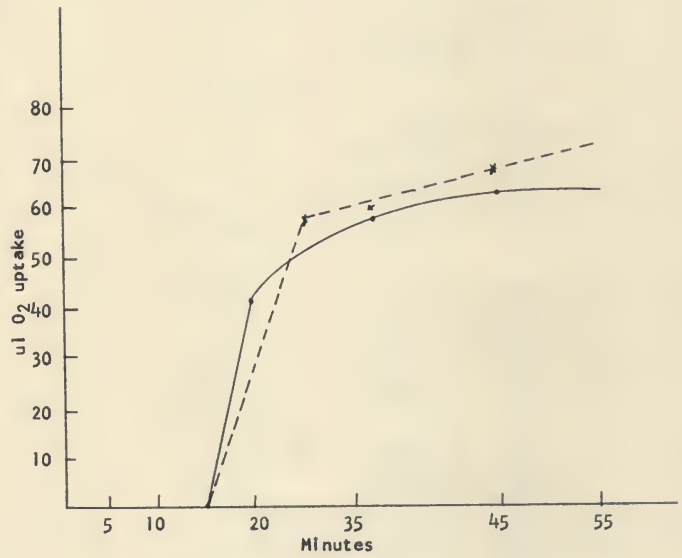

Fig. 4. Effect of starvation on succlnate oxidation by the wild strain, starved cells $(x--x)$ took up 6 ul of oxygen per hour per 0. D. Unit, nonstarved (. .) took up 7.7 ul of oxygen per hour per O. D. Unit. 
cells. This suggested that an inhibltor was present which was not completely effective since the total oxygen uptake by starved and nonstarved cells was not significantly different. A second interpretation, that the starvation resulted in the exhaustion of an essential cofactor, was also possible.

Effect of cell concentration. Having demonstrated the suscepti bility of succinic dehydrogenase to inhibition by oxalacetate, evidence for the accumulation of an internal inhibitor, perhaps oxalacetate, using whole cells was sought. A heavy cell suspension might be expected to oxidize succinate at a faster rate than the more dilute suspensions, because there are more cells present. Such a heavy suspension might also have a greater total oxygen uptake in spite of the presence of a partial inhibitor because oxygen uptake under such conditions of limlting substrate would be complete before an inhibitory effect could become visible. However, if no inhibitor were accumulated the rate of oxidation would be slower in the dilute suspensions because fewer cells are present, but the total volume of oxygen consumed would be the same as in heavy suspensions.

The cells for this experiment were grown as previously described. The optical densities of the suspensions were adjusted as shown in Figure 5. One milliliter of each of the suspensions was used in the experiment.

On the basis of oxygen uptake per unit of optical density, the wild strain showed about 20 per cent greater activity than the mutant. However, there was a considerable variation in respiratory activity among the various cell masses used in different experiments (Table 15). The 
Fig. 5. Effect of decreasing cell density on rate of oxidation of succinate by the wild strain and mutant. A second aliquot of substrate was tipped at 130 minutes in the case of the mutant at the two highest cell densities. In the case of the wild type a second aliquot was tipped at $160 \mathrm{~min}$ when the 0 . D. was 48 and at $180 \mathrm{~min}$ when the 0 . D. was 22 . 

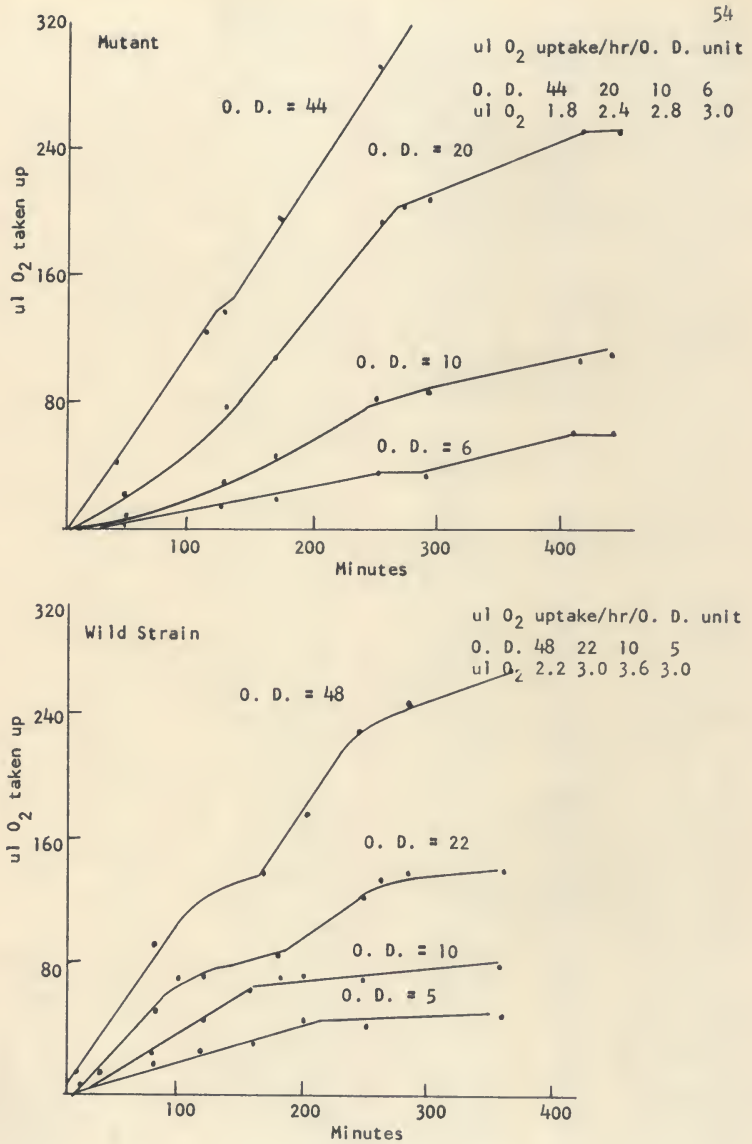
TABLE 15. VARIATION AMONG DIFFERENT CELL MASSES IN RESPIRATORY ACTIVITY WITH SUCCINATE AS SUBSTRATE

\begin{tabular}{|c|c|c|c|c|}
\hline Strain & $\begin{array}{l}0.0 . * \text { of } \\
\text { cell mass }\end{array}$ & El $\mathrm{O}_{2} / \mathrm{hr}$ & $\begin{array}{l}\text { unit } \\
\text { Succinate }\end{array}$ & $\begin{array}{c}\text { Ratio } \\
\text { Succ./End }\end{array}$ \\
\hline Wi Id & 22 & 1.30 & 3.00 & 2.30 \\
\hline Mut ant & 20 & 0.55 & 2.40 & 4.40 \\
\hline Wild & 29 & 0.48 & 3.72 & 7.75 \\
\hline Mutant & 22.5 & 0.80 & 6.49 & 8.70 \\
\hline Wild & 27 & 0.67 & 2.78 & 4.10 \\
\hline Mutant & 27 & 0.22 & 4.66 & 21.0 \\
\hline Wild & 30 & 0.55 & 6.60 & 12.0 \\
\hline Mutant & 30 & 0.98 & 1.95 & 2.00 \\
\hline Wild & 84 & 0.55 & 1.43 & 2.60 \\
\hline Mutant & 84 & 1.10 & 2.14 & 1.90 \\
\hline
\end{tabular}

*0. D. was determined by diluting the suspension $1 / 100$ and measuring turbidity spectrophotometrically. 
per cent increase, in this case, in the rate of oxidation with decrease in cell density was similar in the two strains. The lowest cell concentration in the case of the wild strain showed a decrease in oxidation rate of about 17 per cent, while the mutant oxidation rate increased by 10 per cent. This may have resulted from the activity of a very weak inhibitor, but the rapid resumption of respiration when additional substrate was provided after exhaustion of the first aliquot did not support this view. With the heaviest cell suspensions both strains completely oxidized the substrate, but in the case of the wild strain, the total oxidation was somewhat decreased. The mutant continued to completely oxidize the substrate as cell density was decreased unt 11 , at the lowest cell concentration, it, like the wild strain, attained only about 50 per cent of the totai theoretical oxygen uptake. From these results it was strongly suggested that the action of a metabolic inhibitor accumulating during the course of succinate oxidation was not strong enough to cause the dramatic delay in growth of the wild strain on succinate.

It must again be pointed out that loss of an essential cofactor by leakage into the surrounding medium, in the case of low cell densitles, rather than accumulation of an inhibitor, could also account for the reduction in oxidation rate seen at the lowest cell concentration of the wild type. This possibility has been mentioned previously (see Section 1 , Effect of Starvation).

Respiration of Krebs sycle compounds by cell-free extracts. Stone and Wilson (1952) observed, in extracts of Azotobacter that there was an initial rapid uptake of oxygen when the substrate was fumarate, 
malate or citrate. However, after about ten minutes the respiration on these substrates fell to the level of the extracts respiring succinate. When deproteinized and analyzed, the succinate reaction mixtures showed a fourfold higher concentration of oxalacetate than the controls. Further, addition of glutamate to the extracts which were respiring succinate resulted in a sharp increase in the rate of oxidation.

The object of this experiment was to determine whether a similar phenomenon was occurring in extracts of Salmonella typhimurium wild type. Following the procedure of Stone and Wilson the cells were washed three times, and resuspended in 0.2 per cent $\mathrm{KCl}$. They were disrupted by one passage through the French pressure cell (1950), and the resulting extract was centrifuged at $1475 \times g$ for twenty-five minutes to remove debris and unbroken cells. The supernatant fluid was used in this experiment. The data (Figure 6) showed no difference in the pattern of oxygen uptake between mutant and wild type; neither extract was able to oxidize fumarate, malate or citrate, but both oxidized succinate. The total oxygen uptake with succinate was only enough to give rise to fumarate, and this fact together with the failure of the extracts to respire fumarate suggested that some damage to the enzyme, fumarate, may have occurred during preparation. The whole cells of both strains did oxidize fumarate and malate, and it will be shown in the next section that extracts prepared subsequently had fumarase activity. Therefore, a block at this point in the Krebs cycle did not account for the slow growth of the wild type on succinate. Since no difference between mutant and wild type was apparent the reaction mixtures were not 


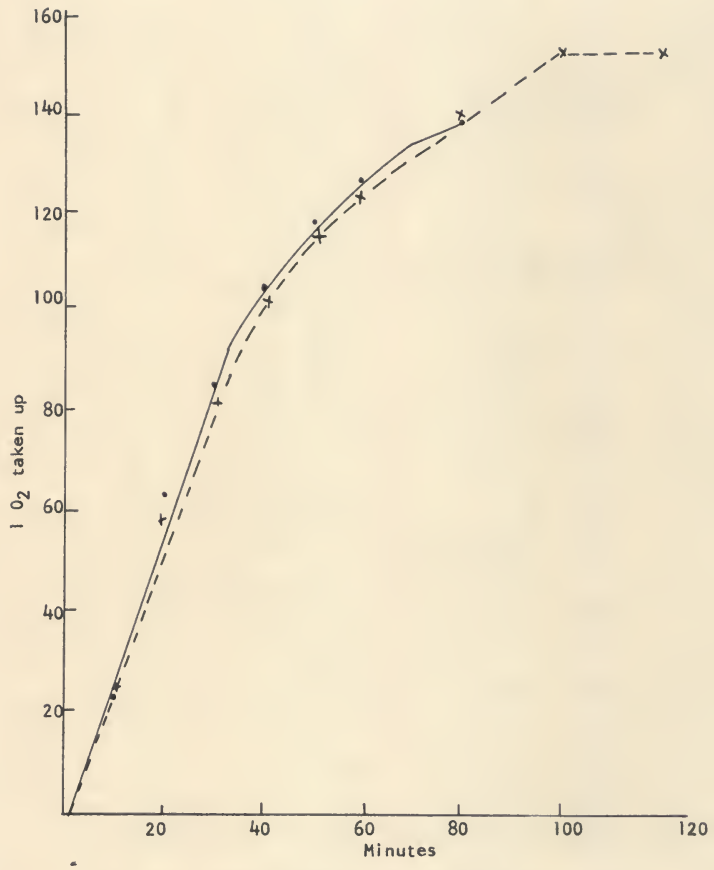

Fig. 6. Oxygen uptake by cell extracts of wild strain $(x--x)$ and mutant $\left(\cdot{ }^{\circ}\right)$ with succinate as the substrate. 
analyzed. No difference in oxalacetate accumulation was expected in view of the oxygen uptake patterns.

\section{Enzyme Studies}

A survey of Krebs cycle and related enzymes was made to determine whether any were lacking or showed less activity in the wild strain. The methods used may be found in the Materials and Methods section. While these experiments were performed on the crude preparations, that is, wi thout any attempt at purification of the cell extracts, condi tions for assays of extracts of both strains were kept constant and the results showing enzyme activity were considered valid on a comparative basis. Absence of enzyme activity in both extracts could have been the fault of the method, and would have been meaningless.

A tenfold difference in isocitritase activity (Table 16) in the glucose-aspartate grown organisms was striking in view of the fact that in previously reported systems (Kornberg, 1961; McFadden and Howes, 1961) glucose suppressed the formation of this enzyme. This finding suggested that the failure of the wild type to grow readily on succinate might be due to exhaustion of acetate pools through condensation of acetate wi th glyoxylate. This possibility has already been mentioned, and it has been demonstrated that acetate enhances the growth of the wild strain on succinate (see Table 11, Section 1). To test this idea isocitritase was induced in the mutant by growing it on acetate. The cells were harvested, washed twice in 0.2 per cent $\mathrm{KCl}$, and inoculated into succinate to give a final concentration of $2 \times 10^{6}$ cells per $\mathrm{ml}$. The rest of the cells were disrupted in the French pressure cell, and the extract assayed for isocitritase as before. Very marked enzyme activity 
TABLE 16. SPECIFIC ENZYME ACTIVITY OF CELL EXTRACTS OF WILD STRAIN AND MUTANT

\begin{tabular}{|c|c|c|}
\hline \multirow[b]{2}{*}{ Enzyme } & \multicolumn{2}{|c|}{$\begin{array}{l}\text { Specific Activity in } \\
\text { O. D. Units/mg Protein/min }\end{array}$} \\
\hline & Wild Strain & Mutant \\
\hline Succinic dehydrogenase $e^{a}$ & 0.031 & 0.034 \\
\hline Fumarase & 0.140 & 0.101 \\
\hline TPN-Malic dehydrogenase & 0.034 & 0.024 \\
\hline Glutami c dehydrogenase & 0.141 & 0.106 \\
\hline Aspartase $e^{b}$ & 0.041 & 0.074 \\
\hline Oxalacetic decarboxylasec & 1.26 & 1.80 \\
\hline Isocitritase ${ }^{d}$ & 0.098 & 0.009 \\
\hline
\end{tabular}

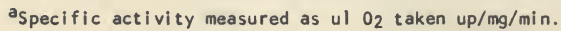

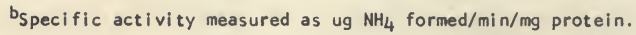

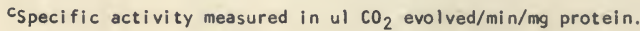

dThe specific isocitritase activity of the mutant cultured on acetate measured 0.960 . D. units/mg protein/min. 
was observed (see footnote $d$, Table 16), but the presence of Isocitritase in the mutant had apparently no effect on its growth in succinate. The Induced cells grew at a rate exactly equal to that of the glucoseaspartate grown control (Table 17), and no difference between the induced and the noninduced cells in the length of the lag was noted. This evidence, therefore, did not support the theory of acetate depletion by isocitritase action, but neither did it disprove it.

\section{Tracer Experiments}

If a block in one of the reactions of the Krebs cycle could account for the fallure of the wild type to grow on succinate then the product of the reaction preceding the block should accumulate. The accumulation of such a product should show up as $\mathrm{c}^{14}$ if labeled succinate were supplled. The experiment described below was deslgned to determine whether any Krebs cycle intermediates did in fact accumulate.

One $\mathrm{ml}$ of a suspension of whole cells was Incubated in Warburg flasks containing in the main compartment, phosphate buffer, $\mathrm{pH} 6.8$, 60 umoles, $\mathrm{MgSO}_{4} \cdot 7 \mathrm{H}_{2} \mathrm{O}, 2$ umoles; distilled water to bring the fluld volume to $3.0 \mathrm{ml}$. The side arm contalned 1.66 umoles of succinic acid $1-c^{14}$ (specific activity -5.8 ucurles/umole), and 7.5 umoles of unlabeled succinate to give about 10 umoles total. Oxygen uptake was measured for $90 \mathrm{~min}$ after which the whole contents of the Warburg vessel were passed through the Hughes Press to disrupt cells. One $\mathrm{ml}$ of $5 \mathrm{~N}$ $\mathrm{H}_{2} \mathrm{SO}_{4}$ was added to one $\mathrm{ml}$ of the cell extract, and the precipitated protein removed by centrifugation. The supernatant fluid was extracted with one $\mathrm{ml}$ of ethyl ether, and $0.3 \mathrm{ml}$ of the ether layer was removed and evaporated to dryness. The residue was resuspended to $0.5 \mathrm{ml}$ of ethyl 
TABLE 17. EFFECT OF ISOCITRITASE INDUCTION ON GROWTH OF THE MUTANT IN SUCCINATE MINIMAL BROTH

\begin{tabular}{lcccc} 
& \multicolumn{4}{c}{$0.0 .425 \mathrm{mu}$} \\
\cline { 2 - 5 } Ireatment & $10 \mathrm{hrs}$ & $14 \mathrm{hrs}$ & $23 \mathrm{hrs}$ & $34 \mathrm{hrs}$ \\
\hline Inducedt & 0.10 & 0.63 & 0.75 & 0.80 \\
Noninduced & 0.13 & 0.66 & 0.76 & 0.89 \\
\hline
\end{tabular}

*Induction of isocitritase was brought about by culturing the cells in acetate minimal broth. 
alcohol; this solution was used for chromatography of fatty acids. Twenty microliters of a similarly treated succinate control were also chromatographed to determine isotope recovery. The remaining portion of the extract $(0.65 \mathrm{ml}$ in the case of the wild type, and $0.95 \mathrm{ml}$ in the case of the mutant) was added to $1 \mathrm{ml}$ of 5 per cent trichloroacetic acid. After centrifuging out the precipitate, I $\mathrm{ml}$ of the supernatant fluid was used to prepare the 2,4 dinitrophenylhydrazones. These derivatives were chromatographed as described previously in the materials and methods section.

The carbon dioxide was collected in 20 per cent $\mathrm{KOH}$, and the solution was removed from the center well quantitatively. After seventytwo hours storage the $\mathrm{CO}_{2}$ was driven off by the addition of concentrated $\mathrm{H}_{2} \mathrm{SO}_{4}$, and collected in $0.5 \mathrm{ml}$ of a 50 per cent solution of Hyamine in methanol (Packard Instrument Company) in a Durham gas vial. The vial was dropped into a scintillation vial and the radioactivity measured.

The oxygen uptake curves of the two organisms were nearly identical (Figure 7). It was not surprising, therefore, that no difference In the accumulation of the Krebs cycle Intermediates could be demonstrated. All of the radioactivity which was recovered was found in the $\mathrm{CO}_{2}$ fraction, but there was no significant difference in the amount of radioactivity between the two strains in any fraction tested (Table 18). This suggested that there was no block in the Krebs cycle itself which could explain the slow growth of the wild type of succinate. Apparently both organlsms could oxidize the substrate to carbon dioxide. 


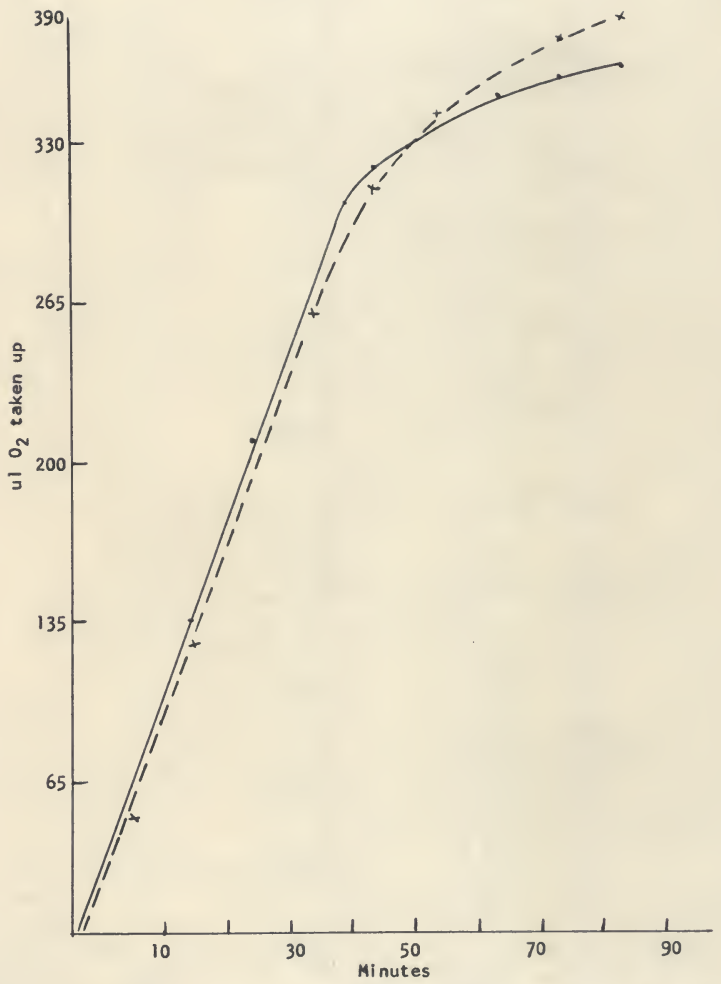

Fig. 7. 0xygen uptake on $\mathrm{C}^{14}$ labeled succinate by whole cells of wild strain $(x--x)$ and mutant $(.$.$) .$ 
TABLE 18. UTILIZATION OF SUCCINATE BY INTACT CELLS

\begin{tabular}{lccccccc}
\hline \multirow{2}{*}{ Organism } & OAA & KG & \multicolumn{7}{c}{ Citrate } & Succinate & Fumarate & Malate & $\mathrm{CO}_{2}$ \\
\hline Mutant & 48 & 40 & 29 & 37 & 29 & 29 & 38,770 \\
Wild strain & 48 & 43 & 34 & 29 & 33 & 30 & 45.809 \\
Background & 30 & & & & & \\
Succinate Control & $1,011 / 20$ & ul & $\left(1.52 \times 10^{5}\right.$ total in $\left.3 \mathrm{ml}\right)$ \\
Total radioactivity input: & 9.6 uCuries $=2.8 \times 10^{5} \mathrm{CPM}$ & $(54.6 \%$ recovered $)$
\end{tabular}




\section{DISCUSSION}

Succinic acid will serve as the sole carbon and energy source for many microorganisms (Stephenson, 1949), among them some strains of Saimonella typhimurium (Engeisberg, 196i). The finding that this substrate would not readily support the growth of the wild strain used in this study was an unexpected result. Even more perplexing was the observation that a mutant produced from this strain by uitraviolet irradiation grew quite readily on succinate. That the biochemical lesion produced by the irradiation, a requirement for aspartate, was not directly associated with the rapid growth rate of the mutant on succinate was verified by the fact that one could seiect wild strain cultures which grew rapldiy on succinate. Delayed growth of the wild strain was also observed when either fumarate or malate was the sole carbon source, but the delay was not so marked as the lag on succinate. Both organisms grew well on citrate. This finding suggested that the Krebs cycle was operative, at least under the conditions empioyed. The only aerobic pathway known for cltrate utilization is through this cycle, and succinate must necessarily be formed and degraded. Thus it was not, at the outset, likeiy that any absolute block in the cycle would explain the observations. Therefore, the most obvious explanation for the slow growth of the wild type on succinate was that the cell was not permeabie to it, due either to loss of a permease or simply to slow diffusion. This idea was not supported by the experimental data. Increases in succinate concentration falled to stimulate the growth rate 
of the wild strain to any marked degree. Furthermore, the oxidation of succinate by whole cells, although somewhat slower than the mutant, indlcated that the substrate could permeate the wild strain. This slower rate of oxidation did not occur consistently, and it did not appear that permeation was the only factor to account for the slow growth of the wild strain with succinate.

The growth yield constants of these organisms on succinate and citrate were almost identical. The similarity of the constants on cltrate suggested that energy-providing mechanisms were the same in both strains. This result implied that both organisms were able to carry out an efficient oxidative phosphorylation, and had a complete cytochrome system. Differences in growth yield constants were apparent when either fumarate or malate was the substrate, but this may reflect differences in permeability, since these compounds are not readlly permeabie.

Since neither a significant permeabllity barrier nor interference with oxidative phosphorylation in relation to succinate utilization were supported by the experimental evidence, it seemed possible that a rate $1 / \mathrm{miting}$ reaction step $\mathrm{might}$ be occurring in the wild strain, but not in the mutant. The effect of Inoculum size seemed to support such a hypothesis. The shortening of the lag perlod by Increasing the Inoculum size suggested that some essentlal growth factor was being inoculated with the cells, probably intracellularly, since all inocula were thoroughly washed. This substance would become avallable to the cells by leakage into the medium, and $\mathrm{might}$ then act as a sparker. The decrease in the rate of oxidation of succinate caused by starvation of 
cells also suggested the presence of an essential growth factor which $\mathrm{might}$ have been depleted by this treatment. The effect of such a rate limiting step might be eliminated by supplying, externally, its reaction product. Addition of supplementary carbon sources revealed that a number of substances would stimulate the growth of the wild strain on succinate. The most effective of these were acetate and pyruvate. Alanine, glycine, and glutamate also showed definite stimulation, but less than that of acetate. It was reasoned that the effect of alanine and pyruvate possibly was to provide acetate to the culture, by deamlnation decarboxylation of alanine and by decarboxylation of pyruvate. Glutamate must stimulate through another mechanism. The stimulatory effect of acetate and acetate precursors suggested that the observed delay of growth on succinate by the wild strain was due to a depletion of internal acetate pools.

A second line of evidence, the demonstration of tenfold greater activity of isocitritase in the wild type, supported the hypothesis of acetate depletion. It suggested that the glyoxylate cycle was operative, and this pathway could promote the rapid depletion of acetate pools by a condensation of glyoxylate, formed through the medlation of isocitritase, with the available acetate to give rise to malate. This could result in cessation of Krebs cycle reactions because of lack of an essentlal component, acetate. If this were the case, then Induction of isocitritase in the fast-growing mutant should cause a long lag when the cells were inoculated into succinate medium. This did not happen; the induced and noninduced mutants grew at exactly the same rate in succinate broth even though a high level of isocitritase, 100-fold greater than in 
the noninduced, was demonstrated in the extract of the induced celis. This evidence did not, therefore, support the hypothesis of acetate depietion by this mechanism.

While not directiy responsibie for the faliure of the wild type to grow readily with succinate as the sole carbon source, the depietion of acetate poois might have an indirect effect by causing oxaiacetate to accumulate. This compound has been shown to be inhibitory to succinic dehydrogenase, in mitochondrla (Pardee and Potter, 1948) and this effect has been substantlated by the experiments reported in this thesis. The effect of glutamate would then be to remove the inhibitor by converting it via a transamination to aspartate. Acetate would be effective in this scheme by condensing with oxalacetate to form citrate. A schematic representation of the reactions concerned in these hypotheses, which are closeiy interacting and difficult to disassociate, is presented be low:

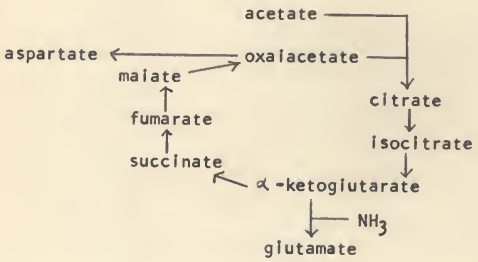

Growth on citrate would be possibie in this scheme because giutamate, produced from a-ketogiutarate, would prevent the accumulation of oxalacetate. 
It was expected that, if the above scheme were correct, oxalacetate could be detected. When intact cells oxidized $c^{14}$-labeled succinate, the labeled carbon did not accumulate in oxalacetate; all of the recovered isotope was found in the $\mathrm{CO}_{2}$ fraction. This appearance of the label in the $\mathrm{CO}_{2}$ makes a lesion in the Krebs cycle itself improbable. Neither of these hypotheses has taken into account the fact that succinate is oxidized by both the mutant and the wild strain. It was considered possible that low concentrations of succinate might be oxidized before sufficient oxalacetate had built up to cause inhibition, or that sufficient acetate would be present to permit small amounts of the substrate to be oxidized. However, if the concentration of succinate were increased or the number of cells decreased an inhibitory effect, measured as a cessation of oxygen uptake, might have been expected. When the concentration of succinate was increased sixfold, as in the isotope experiment (see Figure 7), or when the cell concentration was reduced (see Figure 5), no significant inhibition of oxygen uptake was observed in the wild type as compared to the mutant, but rather there was an increase in rate in both strains at the lower cell densities. At very low cell concentrations a decrease in the oxidation rate of the wild strain on succinate was seen, but this seemed to indlcate that only a very weak inhibitor, if any, was involved. Such an inhibitor, by itself, would not be effective enough to cause the very long delay in growth of the wild strain on succinate. There was considerable variation in respiratory activities with different populations of cells, but this may have been due to the lack of unlformity of the physiological condition of the cells. The cultures used were incubated for ten hours 
and presumably had entered into the stationary phase of growth. Thus, some of the cells would be less active, metabolically, than others, due to senescence, and the number of these might vary with different cultures. The finding that both wild strain and mutant could oxidize succinate essentially to completion suggested, as did the isotope experiment, that there was no enzymatic block in the Krebs cycle Itself. Further support for this view was found in the data concerning Krebs cycle enzyme activity. A survey of these enzymes falled to reveal any significant differences between the wild strain and the mutant.

None of the postulated causes for the slow growth of the wild strain on succinate has been supported by the experimental data. The results so far reviewed indicated that the wild type is permeable to succinate, although it may be slightly less so than the mutant, that it has the same efficlency of energy production as the mutant, and that the Krebs cycle is functional. Any interpretation invoked must account for the abllity of the wild strain to oxidize succinate to an appreciable degree, while it is still unable to grow on $i t$. The only difference between growth and respiration experiments was the presence of ammonium sulfate in the growth flasks. By simulating more closely the growth conditions it might be possible to bring about some change in the respiratory patterns of the mutant and the wild strain. When ammonium sulfate was included in the Warburg flasks a slight difference in oxygen uptake occurred. The mutant showed a reduction in oxygen consumption of nearly 50 per cent, the wild type about 30 per cent. This suggested the possiblilty of a block in assimilation rather than in oxidation. This Is a rather tenuous theory, however, in view of the fact that both 
organisms can grow on eltrate. Presumably the same assimilatory pathway is used with this substrate as with succinate, since both are metabolized through the Krebs cycle and reactlons associated with it. Further, the wild strain also grows on glucose, and this substrate is oxidized, ultimately, through the Krebs cycle. A separate mechanism for the synthesis of amino aclds would have to be proposed in organisms growing on glucose. The only amino acid not formed through the Krebs cycle is alanine, but it can be formed from the catabolism of other more complex amino acids. It is, therefore, difficult to Imagine any block in amino acid synthesis which would permlt growth on cltrate and glucose but not on succinate.

The nature of the eventual adjustment of the wild straln to succinate utilization was not entlrely clear from the results obtalned. The modifled fluctuation test seemed to indicate that the eventual growth of the organism was due to a physiological adaptation, perhaps to Induction of an enzyme of the formation of critical levels of an essentlal metabollte. As shown by Engelsberg and Stanier (1949), however, such a result, that is, eventual growth in all tubes, could be due to mutation occurlng during growth on Impuritles in the medium. Slow growth of the cells on succlnate might also have occurred, but In this case such a wide fluctuation in the time of appearance of turbldity in the various tubes would not be expected.

When cell populations arising from small inocula in succlnate medlum were transferred to the glucose-aspartate medium, either agar or broth, and then reinoculated into succlnate minimal broth, they retained the abillty to grow rapidly. This suggested that the growth of the wild strain on succinate was actually the growth of a mutant. However, when 
the experiment was done using solid media instead of llquid, and colonies were transferred from succinate agar to tryptlcase soy agar plates, then back to succinate, no fast-growing colonies were found. The presence of a few rapidly growing cells in close proximity to the slower-growing organisms, such as might be the case in Ilquid medium, might promote more rapid growth of the slow strain. This possiblilty was not substantlated by experiments. When a few of the rapidly growing cells were added to a large population of the slow strain, and the mixture was plated, there was no increase in the number of fast-growing cells over the number originally put in.

Thus some experiments seemed to Indicate that growth was due to mutation, while others seemed to show that it was not. it is possible that both mutation and physiological adaptation were occurring; the culture used in these experiments may consist of a highly variable population in which a large number of cells have a high mutation rate. This would account for the variation observed in the experiments reported.

This problem has proved to be considerably more complex than it appeared at first. All of the logical explanatlons have been complicated by the inconsistency between growth and respiration, so that the more apparent interpretations of the data are invalidated. While the exact nature of the metabolic block has not been discovered the ablilty of the wild type to grow with succinate in combination with acetate suggested that the cell was unabie to synthesize acetate or acetyl CoA in sufficlent quantities to support growth. The evidence seemed to point to a block, not in the Krebs cycle itself, but in some secondary but essentlal reaction in which acetyi Coenzyme $A$ is a component. In the metabolic 
conversion of glucose to fatty acids acetyl Coenzyme $A$ is known to be a necessary intermediate (Fruton and Simmonds, 1959). It is aiso a reactant in the formatlon of ornithine from glutamic acld, and acetate is required for the formation of leucine froma-ketovalerate. The function of glutamate, in addition to that of a source of amino groups, might be to suppiy acetyl Coenzyme A through some catabollc process. Acetyl Coenzyme A is also a reactant in the acetylation of amines. For example, acetyl Coenzyme A can react with giucosamine-6-phosphate to form acetyl-glucosamine-6phosphate, an intermediate in cell wall synthesis. Acetyl Coenzyme A is thus a reactant in several essentlal blosynthetic react lons which may function subopt lmaliy in the metabolism of the wild straln growing on succinate.

The additional possibility exists that the observed effect, slow growth of the wild strain on succinate, is due to a comblnation of causes. Thus each of the explanations presented and tested $\ln$ thls thesis may only account for part of the phenomenon, so that the phenomenon would then result from the summation of all of the interacting factors. Vlewed in this way, it would be easler to understand why none of the hypotheses, alone, could account for the slow growth of the wild strain on succlnate. 
The objective of this thesis was to study the metabolic mechanism by which a Salmonella typhimurium wild type and a mutant derived from It utillzed succinate as a sole carbon source. The following polnts were brought out in the course of the investigation:

1. The initiation of growth of the wlld type with succinate, fumarate, or malate as sole carbon source was delayed by a period of 40 to 70 hours over that of the mutant. Neither strain grew readily with acetate, but both utilized citrate at the same rate.

2. Growth of the wild type with succinate as sole carbon source was stimulated by the addition of acetate, alanine, or glycine.

3. Large increases in succinate concentration brought about only a slight decrease in the length of the delay on succinate.

4. No real difference in growth yield constants could be demonstrated suggesting that both strains had simllar energy-producing mechanisms.

5. The eventual growth of the wild type in succlnate broth proved to be a mutational adaptation which remained stable through transfer on nonsuccinate medium.

6. A decreasing lag period was observed with increasing inoculum size, probably due to the inclusion of a large number of mutants.

7. The oxidation rate of the wild type with succinate was, on the average, only 20 per cent less than that of the mut ant.

8. A decrease in cell concentration of the mutant in the Warburg vessels resulted in an increased rate of oxygen uptake. The rate of oxygen uptake in the presence of $\left(\mathrm{NH}_{4}\right)_{2} \mathrm{SO}_{4}$ was slightly higher in the wild type implying that a regulatory mechani $\mathrm{sm}$ might be in the pathways of assimilation. 
9. Delay of growth on succinate in the wild type was thought possibly to be due to the accumulation of some inhibitory product, perhaps oxalacetate. This compound was shown to inhibit succinate dehydrogenase when added to the reaction mixture, but no such accumulation could be demonstrated in tracer experiments. Totai oxygen uptake was not reduced in the presence of excess succinate as would be expected If such an inhibitor were accumulating.

i0. No significant difference in Krebs cycie enzyme activity could be demonstrated, with the exception of isocitritase, However, when this enzyme was induced in the fast-growing mutant no inhibition of growth on succinate was observed.

It was concluded, therefore, that the block to succinate utilization in the wild strain occurred in the assimilatory pathways, and that it might be associated with a shortage of acetate or acetyi Coenzyme $A$. 


\section{LIST OF REFERENCES}

AJL, S.J. 1950. Acetic acid oxidation by Escherichia coll and Aerobacter aerogenes. J. Bacteriol. 52:288-293.

AJL, S. J., M. D. KAMEN, S. L. RANSON, D. T. 0. WONG. 1951. Studies on the mechanism of acetate oxidation by Micrococcus lysodeikticus. J. Biol. Chem. 189:859-867.

ALTENBERN, A. and H. HOUSEWRIGHT. 1952. Carbohydrate oxidation and citric acid synthesis by smooth Brucella abortis, strain 19. Arch. Biochem. Biophys. $36: 345-356$.

BARRETT, J., A. LARSON and R. KAILIO. 1953. Adaptive lag of Pseudomonas fluorescens toward citrate. J. Bacteriol. 65:187-192.

BERNATH, P. and T. P. SINGER. 1962. Succinic dehydrogenase. Methods in Enzymology $\underline{V}:$ 597-602.

BRINKMANN, Manual. 1962. Technical bulletin No. 22. Brinkmann Instruments, Inc., Long island, New York.

BURTON, A. and H. KREBS. 1955. Oxalacetic decarboxylase. Methods in Enzymology 1:753-754.

BUSH, I. E. and T. D. R. HOCKADAY, 1962. Chromatography of some 2,4 dinitrophenylhydrazones in acid systems. J. Chromatog. 8: $433-441$.

CAMPBELL, J. J.R. and F. N. STOKES. 1951. Tricarboxyllic acid cycle in Pseudomonal aeruginosa. J. Biol. Chem. 190:853-858.

DAS, N. D. 1937. Studies of the inhibition of succinic and lactic-malic dehydrogenases. Biochem. J. 31:1124-1130.

DAVIS, B. D. 1948. Isolation of biochemically deficient mutants of bacteria by penicillin. J. Am. Chem. Soc. 70:4267.

DAVIS, B. D. 1949. The isolation of biochemically deficient mutants of bacteria by means of penlcillin. Proc. Nat. Acad. Sci. 35:1-9.

DELWICHE, E. A. and S. F. CARSON. 1953. A citric acid cycle in Propionibacterium pentosaceum. J. Bacteriol. 65:318-322.

EISENBERG, M. A. 1953. Tricarboxylic acid cycle In Rhodospirillum rubrum. J. Biol. Chem. 203:815-835. 
ENGLESBERG, E. and R. Y. STANIER. 1949. The relationship between growth and mutation in Pseudomonas fluorescens. J. Bacteriol. 58: 171-180.

ENGELSBERG, E., J. A. WATSON and P. A. HOFFEE. 1961. The glucose effect and the relationshlp between glucose permease, acid phosphatase, and glucose resistance. Cold Spring Harbor Sym. of Quant. Biol. 26: $261-276$.

FRUTON J. S. and S. SIMMONDS. 1959. General Biochemistry, 2nd ed., John WIley and Sons, Inc., New York, p. 484.

FUKUMI, H., E. SAYAMA, and R. NAKAYA. 1953. $C_{4}$-dicarboxylic acid cycle and Salmonella typhi. Jap. J. Med. Sci. Blol. 5:487-492.

GILVARG, G. and B. D. DAVIS. 1956. The role of the tricarboxylic acid cycle in acetate oxldation In Escherichia coli. J. Blol. Chem. 222: 307-319.

GOLDMAN, D. S. 1956. Enzyme systems In Mycobacterla. I. isocitric degydrogenase. J. Bacteriol. 21:732-736.

GRUNDIG, E. 1961. Bestimmung der Ketosauren in Korporflussigkeit und Geweben. Clinica, Chem. Acta 6:331-336.

HERZBERG, M. 1962. Living organisms as immunizing agents against experimental Salmonellosis In mice. J. Inf. Dis. 111:192-200.

HUGHES, D. E. 1951. A press for disrupting bacteria and other microorganisms. Britlsh J. Expt'I Pathol. 32:97-109.

KARLSSON, J. L. and H. A. BARKER. 1948. Evidence against a tricarboxyllic acid cycle in Azotobacter agllis. J. Blol. Chem. 175:913-921.

KORNBERG, G. L. and N. B. MADSEN. 1957. Synthesls of $c^{4}$-dicarboxylic aclds from acetate by a glyoxylic bypass of the tricarboxylic acid cycle. Biochem. Biophys. Acta 24:651-653.

KREBS, H. and W. A. JOHNSON. 1937. Citric acld in intermediate metabolism in anlmal tissues. Enzymologia $\underline{4}: 148-156$.

LARA, F. J. S. and J. L. STOKES. 1952. Oxidation of citrate by Escherichia coll. J. Bacteriol. 63:415-420.

LEDERER and LEDERER. 1957. Chromatography. 2nd Ed., Elsevier Publishing Co., New York.

Merck Index of chemicals and drugs, 7 th ed. 1960. P. G. Stretcher, ed. Merck and Co., Inc., Rahway, New Jersey, p. 761. 
MiLNER, H. W., N. S. LAWRENCE, and C. S. FRENCH. i950. Colloidal dispersion of chloroplast materiai. Science 111:633-634.

NOViCK, A. 1955. Growth of bacteria. Ann, Rev. Microbiol. 2:99-110.

OCHOA, S., A. H. MEHLER, and A. KORNBERG. 1948. Biosynthesis of dicarboxyiic acids by $\mathrm{CO}_{2}$-fixation. J. Biol. Chem. 174:979-1000.

OLSON, J. A., and C. B. ANFINSON. 1952. Crystalization and characterization of i-giutamic acid dehydrogenase. J. Biol. Chem. i $97: 67-79$.

PARDEE, A. and V. R. POTTER. 1948. Inhibition of succinic dehydregenase by oxalacetate. J. Biol. Chem. 176: 1085-i094.

RACKER, E. i950. Spectrophotometric measurements of the enzymic formation of fumaric and cisaconotic acids. Biochem. Biophys. Acta 4: $211-214$.

REEVES, H. and S. J. AJL. 1960. Occurrence and function of isocitritase and malate synthetase in bacteria. J. Bacteriol. 29:341-345.

RUFFO, A. A., G. ADINOLFi, G. BUDILLON, and G. CAPOBIANCO. 1962. Control of the citric acid cycle by glyosyliate. Biochem. $J$. 85: 589-600.

SAZ, H. J. and L. O. KRAMPITZ. 1954. The oxidation of acetate by Micrococcus lysodiekticus. J. Bacteriol. 67:409-418.

SAZ, H. J. and L. O. KRAMPITZ. 1955. Oxidation of acetate by extracts of Micrococcus lysodiekticus. J. Bacteriol. 69: 288-292.

STEPHENSON, M. Bacterial Metabolism, 3rd ed., i949. Longmans, Green and Company, New York, p. 88.

STONE, R. W. and P. W. WILSON. 1948. The effect of oxalacetate on oxidation of succinate in Azotobacter extracts. J. Bacteriol. 69: 619-622. SWIM, H. E. 1953. Thesis. p. 96. Western Reserve University, Cleve-
iand, Ohio.

SWIM, H. E. and L. O. KRAMPITZ. i954. Acetic acid oxidation by Escherichia coli; idence for the occurrence of a tricarboxyic acid cycle. J. Bacteriol. 67:419-425.

UMBARGER, H. E. 1961. End-product inhibition of the initial enzyme in a biosynthetic sequence as a mechanism of feedback control. Ann. Symp. Soc. Gen. Physiol. 2:67-86. 
UMBREIT, W. W., R. H. BURRIS, and J. F. STAUFFER. 1964. Manometric Techniques. 4th Ed. Burgess Publishing Co., Minneapolis, Minnesota, pp. 1-18.

WILLIAMS, V. R. and R. T. McINTYRE. 1955. Preparation and partial purification of aspartase from $\underline{B}$. cadaveris. J. Biol. Chem. 217: $467-477$. 


\section{BIOGRAPHICAL SKETCH}

Janet A. Rowe was born in South Bend, Indlana, and at tended grammar and secondary schoois there. She recelved her B.S. degree from St. Mary's College, South Bend, and taught for three years following her graduation at Holy Cross Central School of Nursing. After recelving her M.A. degree from Indiana University she was employed in the research laboratorles of Parke, Davis and Company for one year and by the Upjohn Company for one year. She attended the graduate school at the University of Illinois for two years, and transferred to the University of Florida where she is a candidate for the degree of Doctor of Philosophy. 
This dissertation was prepared under the direction of the chairman of the candidate's supervisory committee and has been approved by all members of that committee. It was submitted to the Dean of the College of Agriculture and to the Graduate Council, and was approved as partial fulfillment of the requl rements for the degree of Doctor of Phil losophy.

December 19, 1964

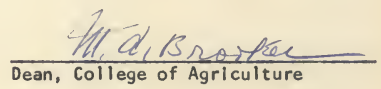

Dean, Graduate School

Supervisory Committee:

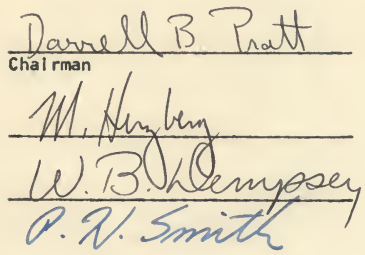

